\title{
KORRUPTION: ORSAKER, EFFEKTER OCH STRATEGIER FÖR BEKÄMPNING ${ }^{1}$
}

Korruptionen har kommit att uppmärksammas allt mer under senare år och har i många länder blivit en stor samhällsfråga. En ny syn på korruptionen har vuxit fram. Dess samhälleliga skadeverkningar framstår som obestridliga och dessa verkningar har kommit att bli allt mer kända världen över.

Strategier för bekämpning av korruption präglas av en strävan att få bukt med grundläggande förhållanden som gör korruption möjlig, såsom regleringar, monopol och andra delar av den ekonomiska politiken. Strategierna tar därför i hög utsträckning sikte på institutioner (i motsats till individer), avreglering, privatisering, konkurrens m. m., medan det juridiska systemet inklusive straffrätten intar en relativt undanskymd plats. Detta bygger i viss mån på en felsyn. Många av de grundläggande förhållandena kan inte avlägsnas, om man inte vill nöja sig med en nattväktarstat. De renaste länderna i världen, inklusive de nordiska, är inte de länder där möjligheterna till korruption är små. En stor del av rättssystemet är därför centralt för att korruptionen skall kunna hållas tillbaka.

1 Texten är en bearbetad version av författarens «Shihata Distinguished Lecture», arrangerad av Centre for Commercial Law, Queen Mary and Westfield College, University of London/IFLU London Forum Initiative (maj 2005). Föreläsningen sammanfattar författarens erfarenheter från korruptionsbekämpningsprojekt i Bolivia (Världsbanksfinansierat), Vietnam (Sida-finansierat) samt ett uppdrag på västra Balkan för Utrikesdepartementet.
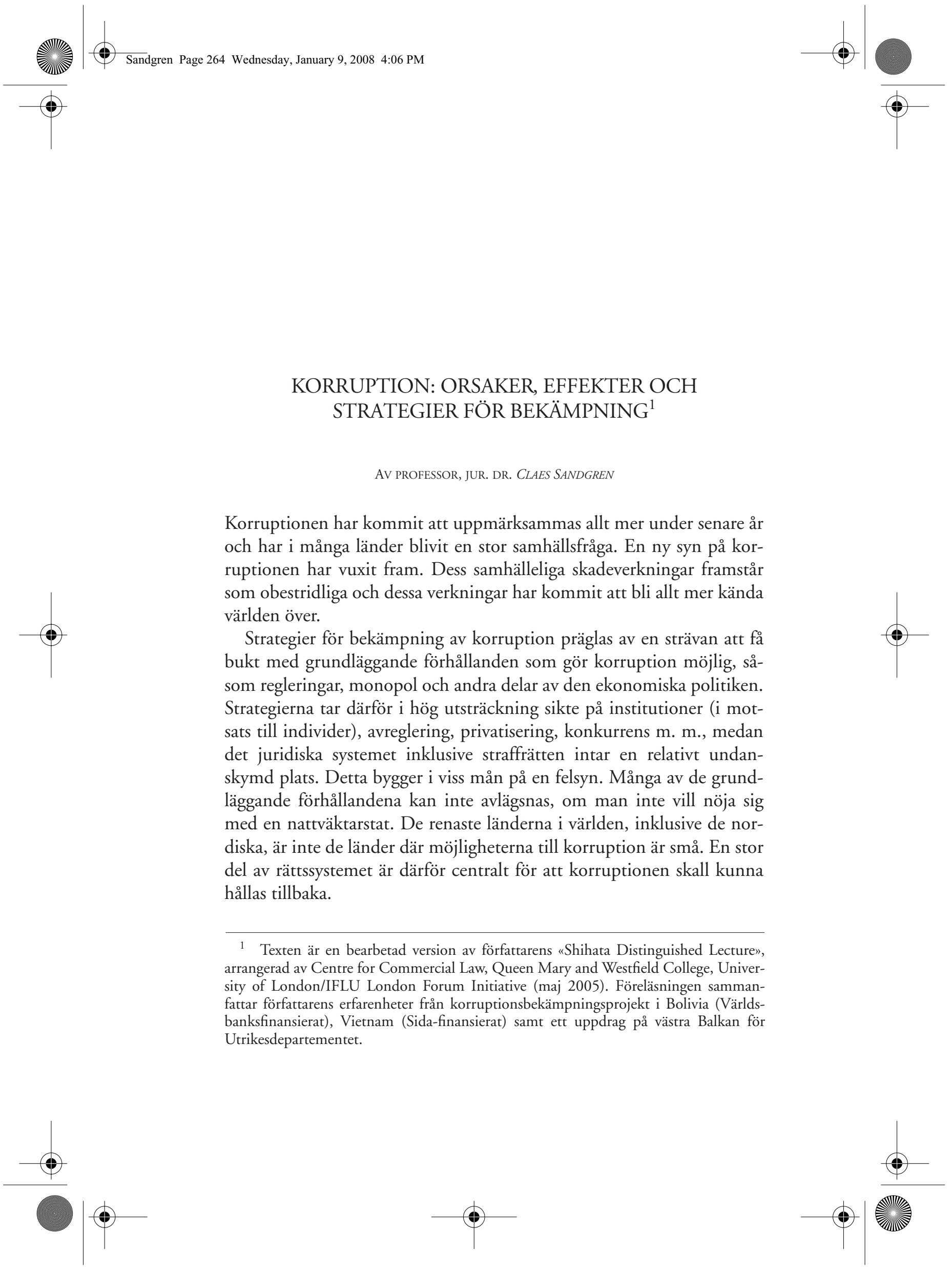
Stora delar av rättssystemet har en funktion att fylla för korruptionsbekämpningen. Exempel är regler om öppenhet och insyn, upphandling, etablering av företag, partifinansiering, jäv och intressekonflikter, mediers oberoende, maktdelning, utkrävande av ansvar av politiker och högre tjänstemän, skydd åt sanningssägare inom institutioner, internrevision, konkurrensregler o.s.v. Dessa regler har inte som uttalat syfte att motverka korruption men reglerna och de organ som tillämpar dem är centrala för ett samhällsstyre av det slag som är en motvikt mot vitt spridd korruption. Straffrätten kan ses som rättssamhällets spjutspets mot korruption i den mån som den riktas mot personer som har hög ställning i samhället.

\section{Varför har korruptionen hamnat i blickfanget?}

Korruptionen har kommit att uppmärksammas allt mer under senare år och har i många länder blivit den stora politiska samhällsfrågan. I december 2003 antogs en FN-konvention mot korruption. Konventionen, som ännu inte trätt i kraft, är det enda instrument som antagits på global nivå riktat mot korruptionen i världen. Det är också först de senaste åren som nordiska myndigheter på ett institutionaliserat sätt börjat angripa korruption i samband med nordiska företags agerande utomlands, internationellt utvecklingssamarbete och annan internationell verksamhet.

\subsection{En ny syn på korruption och utveckling}

I ett tidigare skede, för 20 eller 30 år sedan, var det en allmän uppfattning att korruptionen i utvecklingsländerna («syd») var en följd av underutvecklingen. Därav drog man slutsatsen att korruptionsbekämpningen måste få bero till dess att utvecklingen skjutit fart. Det rådde också en stark kulturrelativism; korruptionen sågs som en del av kulturen i syd. Synen på korruptionen och dess bekämpning löpte parallellt med synen på demokrati och mänskliga rättigheter. Strävan att främja dessa fick anstå av samma skäl som här nämnts i fråga om korruptionen. Dessa företeelser - korruption, enpartistat och förtryck - hörde för övrigt nära samman med ländernas styresskick. Man ansåg att det borde vara förbehållet varje land att bestämma sitt styresskick.

Numera råder närmast motsatt synsätt. Hederlighet, demokrati och
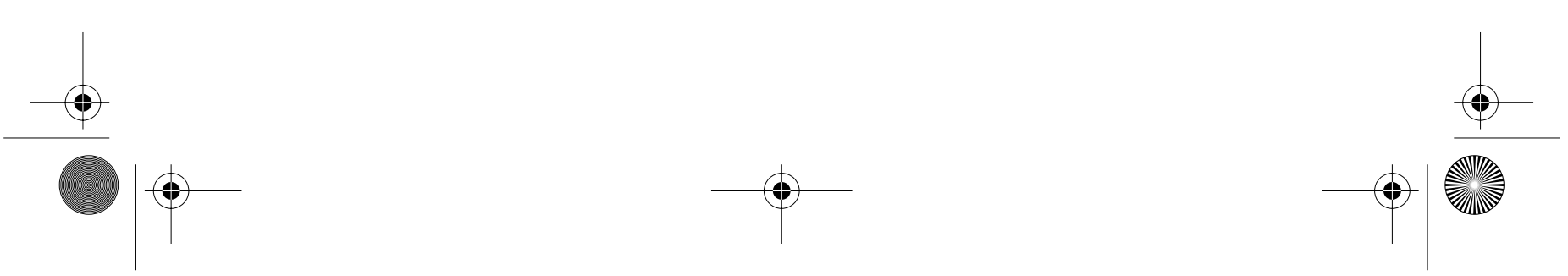
mänskliga rättigheter ses som nödvändiga steg i arbetet att åstadkomma utveckling. Korruption ses som orsak till fattigdom snarare än som verkan, låt vara att sambandet går i bägge riktningarna. Världsbanken har t.o.m. hävdat att korruption är det främsta hindret för utveckling i världen. Korruption och förtryck försvaras inte längre med att de är kulturellt betingade och i-länderna finner det legitimt att påtala brister i styresskicket i syd liksom i Central- och Östeuropa («öst»).

\subsection{Fakta om korruptionen}

Det var länge en vanlig uppfattning att det (definitionsmässigt) inte var möjligt att bilda sig en uppfattning om korruptionens spridning, omfattning eller närmare karaktär. Detta synsätt bidrog till att man hade överseende med korruptionen. Det var lätt att intala sig att den måhända inte var så omfattande och dess karaktär inte så allvarlig som man kunde befara. Också i detta avseende är situationen nu en annan. Det finns numera siffror att tillgå på korruptionens omfattning. Enligt beräkningar av Världsbanken uppgår korruptionen globalt till en biljon (1 000000000000$)$ dollar, vilket motsvarade $3 \%$ av världens samlade intäkter år 2002. Dessa siffror är naturligt nog osäkra men bygger på de mätningar som bl. a. Världsbanken gjort under senare år.

Insikten om korruptionens skadeverkningar har ökat väsentligt. Denna insikt är i sin tur beroende på två omständigheter. Den ena är att forskningen på ett övertygande sätt visat de skadliga effekterna av korruption. Den andra är att denna kunskap fătt vid spridning. Den våg av demokratisering som gått fram i såväl syd som öst är här hjälpsam. Också medieutvecklingen, särskilt genomslaget för Internet, har haft stor betydelse för denna folkbildning.

\subsection{Opinionsbildning}

Korruptionens utbredning och följder har fått starkt ökad uppmärksamhet världen över under det senaste decenniet på grund av den opinionsbildning som bl. a. olika organisationer bedrivit. Chefen för Världsbanken förklarade 1995 krig mot korruptionen, något som fungerat som en väckarklocka världen över. Transparency International, som grundades 1993 av några jurister från Världsbanken och har ca. 90 na-
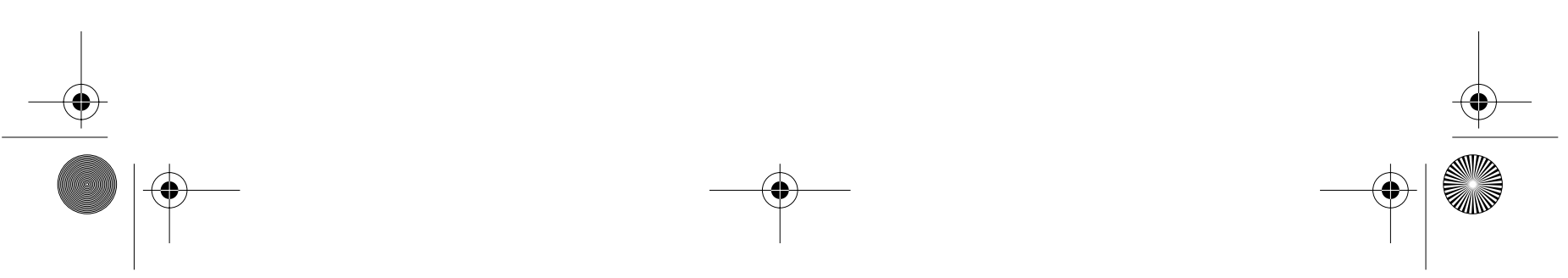
tionella kontor (numera också i Norden), skaffade sig snabbt en respekterad ställning. TI har genom sitt Corruption Perception Index (CPI), som publicerats sedan 1995, fått stort genomslag för sitt arbete. Detta index förtecknar ett stort antal länder efter graden av «perceived corruption», nämligen hur korruptionen uppfattas av företrädare för företag, akademiker och riskanalytiker i landet. TI publicerar också ett Bribe Payers Index (BPI) som redovisar sannolikheten att företag i industriländer betalar mutor.

Ett stort antal andra organisationer bedriver opinionsbildning mot korruption. Ett exempel är Global Compact som är ett internationellt nätverk bildat i FN:s hägn år 2002. Ett annat exempel är Utstein Anti-Corruption Centre som bl. a. verkar för att kunskap och resurser avseende korruption tas till vara och också informerar om de antikorruptionsaktiviteter som dess medlemsstater bedriver. Centret grundades av Nederländerna, Norge, Tyskland och UK till vilka Canada och Sverige anslutit sig.

\subsection{Utvecklingsinstitutioners policyändringar}

Många utvecklingsinstitutioner - såväl bilaterala givarorganisationer som internationella utvecklingsbanker - har fäst ökad uppmärksamhet vid korruptionen och dess skadeverkningar. Ett skäl är att synen på utvecklingssamarbete förändrats. Tidigare användes biståndsmedel i stor utsträckning för direkt stöd till näringsverksamhet, t. ex. jordbruk och industri i u-länderna. Numera riktas ansträngningarna mer mot att skapa förutsättningar för sådan verksamhet. Det betyder att institutioner, ramverk, kompetens och liknande kommer i fokus och därmed också korruption. Om denna grasserar, skadar det förutsättningarna för produktiv verksamhet, varför korruption betraktas som ett avgörande utvecklingshinder.

\subsection{Framgångar för korruptionsbekämpning}

Det är väl känt att Storbritannien och USA med framgång reformerade sina förvaltningar på 1800-talet. Det har likväl rått en uppfattning att det är ytterst svårt att få bukt med korruptionen i ett land där denna slagit rot. Erfarenheterna från senare år visar att det inte behöver vara så. Framgångsexempel är Hong-Kong, Singapore, Republiken Korea (Syd-
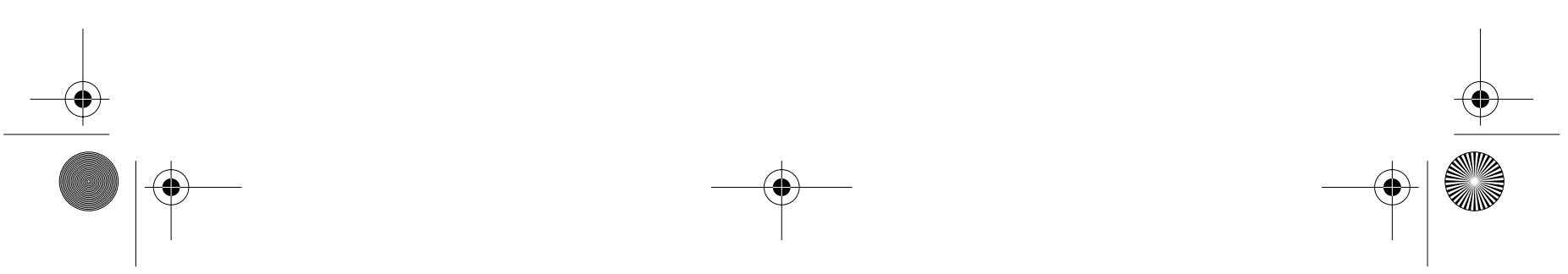
Korea) och Taiwan. Även vissa länder i Latinamerika har genomfört lyckosamma reformer. Det är naturligt att dessa framgångar inger optimism och inspirerar till nya tag på många håll i världen.

\subsection{En ny syn inom näringslivet}

Det finns klara tecken på att företag allt mer tar avstånd från korruption och önskar avhålla sig från bestickning som affärsmetod. De inser att detta är en dyrbar metod att göra affärer, att den utgör grogrund för illojalitet inom den egna organisationen och för övrigt är på väg att bli allt mer riskabel för ansvariga befattningshavare. Kanske har det också haft en inverkan att det avslöjats ett stort antal redovisningsskandaler och etiskt tvivelaktiga förfaranden vilka allvarligt skadat förtroendet för delar av näringslivet.

Näringslivets egna organisationer agerar allt mer resolut mot korruption. Internationella Handelskammaren (ICC) verkar för självreglering inom näringslivet och har $\mathrm{i}$ det syftet utfärdat riktlinjer benämnda "Rules of Conduct on Extortion and Bribery in International Business Transactions», en första version redan 1977. ICC har också utarbetat en handbok om bekämpning av korruption («Fighting Corrupting: A Corporate Practice Manual») samt inrättat en "Commission on Anti-Corruption». En viktig aspekt på Kammarens ansträngningar är att korruption snedvrider konkurrensen mellan företag. Också World Economic Forum har tagit ett initiativ, «Partnership Against Corruption Initiative» (PACI). Detta initiativ som lanserades år 2004, bygger på TI:s «Business Principles for Countering Bribery» (BPCB). TI har för övrigt också utarbetat en «Integrity Pact» (IP) som har syftet att motverka korruption i samband med offentlig upphandling. "Extractive Industries Transparency Initiative» (EITI) har som syfte att öka öppenheten angående betalningar till stater och staters intäkter från utvinningsindustrier.

\subsection{EU och EU-utvidgningen}

EU har på senare år pekat på korruptionen i kandidatländerna som ett hinder för medlemskap och därför kraftfullt betonat vikten av att bekämpa den. Vitt spridd korruption bland polis, domstolar, tullen och andra myndigheter $\mathrm{m}$. fl. är hinder för den inre marknaden, gräns-
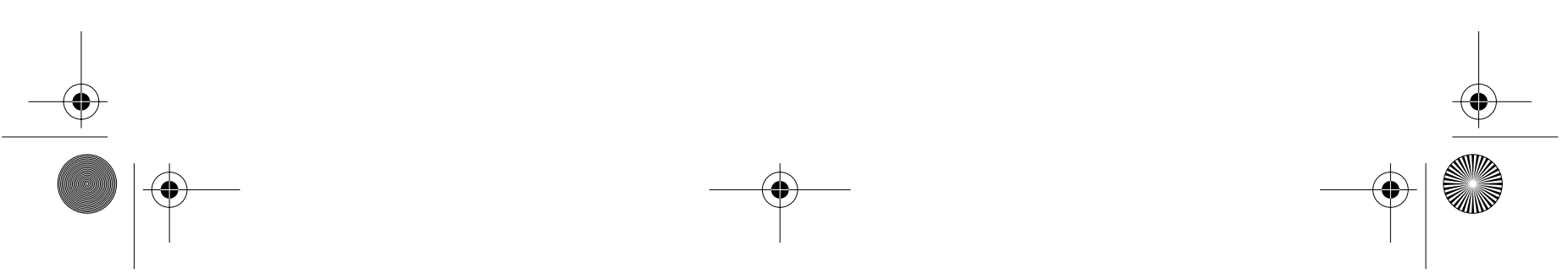
kontroll, bekämpning av organiserad brottslighet m. m. Korruptionsbekämpningen har lyfts fram på politisk nivå men också varit central inom ramen för biståndsprogrammen (Phare, Tacis och CARDS). EU har härigenom gett en stark impuls till alla länder i Central- och Östeuropa att angripa korruptionen.

\subsection{Korruption, terrorism och organiserad brottslighet}

Terrorism och organiserad brottslighet har kommit att få en större spridning, grövre karaktär och vådligare konsekvenser. De instanser som är satta att bekämpa terrorism och organiserad brottslighet - i första hand polis, tull och åklagare - blir naturligtvis långt mindre framgångsrika i denna brottsbekämpning om korruptionen är vitt spridd inom dessa instanser. Det har lett till att såväl USA som EU med hjälp av politiska och ekonomiska påtryckningar samt bistånd börjat påverka korruptionsbekämpningen i länder som uppfattas som härdar för terrorism och organiserad brottslighet. Albanien, Indonesien och Pakistan kan nämnas som exempel. Även penningtvätt har kommit att förbindas med korruption. Skälet är att penningtvätt i normalfallet avser pengar som härrör från brottslig verksamhet vilken kan inbegripa korruption eller underlättas av korruption. Den nära kopplingen mellan organiserad brottslighet och korruption illustreras av att det är FN:s organ mot droger och brottslighet (UNODC) som utsetts att vaka över tillämpningen av FN:s antikorruptionskonvention.

\section{Vad är korruption?}

(a) Den typ av korruption som är mest påtaglig och som direkt berör medborgarna i ett stort antal länder är vardagskorruptionen. Det är de mutor som poliser, tulltjänstemän, läkare, tjänstemän inom skatteförvaltningen o.s.v. kräver som ett led i sin dagliga yrkesverksamhet. Det kan t. ex. vara en lärare som kräver en summa av föräldrarna till ett barn för att det skall få godkänt betyg i skolan eller en skatteindrivare och en skattskyldig som delar på det belopp som skall levereras till staten. Denna s. k. petty corruption - ibland betecknad såsom administrativ eller byråkratisk korruption - är på inget vis oskyldig eftersom den förgiftar samhällsklimatet, missgynnar betalningssvaga familjer och har negativa verkningar för samhällsekonomin.
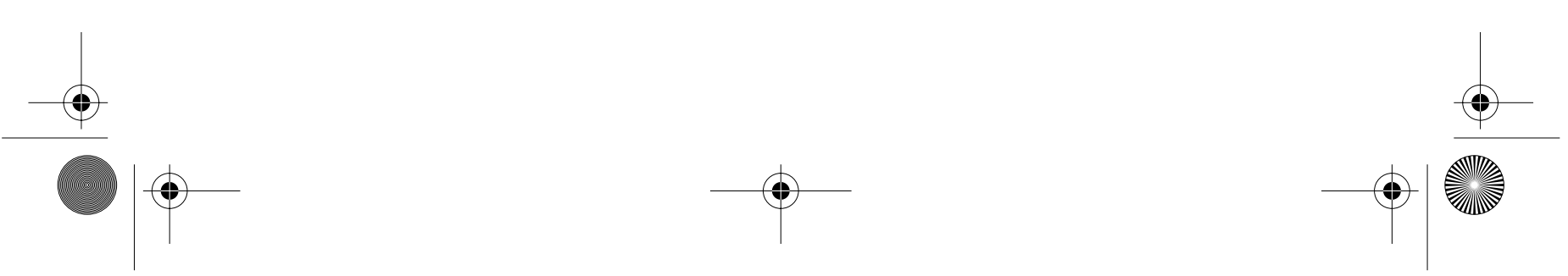
(b) En annan kategori av korruption är s. k. grand corruption. Det handlar då om mutor som företag lämnar i samband med stora upphandlingar, t. ex. för att få infrastrukturella kontrakt eller kontrakt på försäljning av vapen. Två varianter av «grand corruption» är s. k. «state capture» respektive politisk korruption.

«State capture» innebär att man «fångar» staten i syfte att påverka centrala funktioner; staten tjänar en begränsad grupps intressen, t. ex. en affärsgrupp eller en politisk gruppering. Ett exempel är att företag genom mutor påverkar ett lands lagstiftning, institutioner, skatte- eller annan regeringspolicy. En annan variant är att «oligarker» skaffar sig säte i parlamentet genom att köpa ett parti och påverkar lagstiftning som kan skada eller gynna vissa typer av företag; exempel är stater i öst såsom Ukraina. Som synes kan «state capture» innebära att man söker ändra spelreglerna, inte bara påverka tillämpningen av dessa. «State capture» kan också vara att vrida brottsbekämpningen bort från en viss brottstyp eller ett visst geografiskt område eller påverka tullens eller skatteförvaltningens arbete i stort.

«Politisk korruption» definieras av TI såsom «abuse of entrusted power by political leaders for private gain». Den är allvarlig därför att den kan urholka demokratin. Det förekommer framför allt tre former. En sådan är finansieringen av politiska partier. Den är ett särskilt känsligt kapitel i många länder där det statliga partistödet är ringa, varför partierna är beroende av bidrag för sin finansiering. Den andra formen gäller svårigheter att ställa politiker inför rätta för mutbrott. Del av detta problem är även svårigheter att spåra och återvinna offentliga medel som gömts undan på bankkonton i utlandet. Den tredje gäller företags och organisationers betalningar till politiker i utbyte mot inflytande för företaget respektive organisationen. Företags bestickning av politiker för att vinna anbudstävlingar kan också ses som en form av politisk korruption. $^{2}$

(c) «Kompisinflytande» («crony bias / crony capitalism») innebär att stat, näringsliv och intresseorganisationer är sammanflätade i nätverk som kan utöva inflytande och skaffa sig ekonomiska fördelar utan att mutor betalas. Det kan innebära att toppolitiker kan räkna med att få

2 En ytterligare fråga gäller politiska partiers röstköp. Detta är egentligen inte en form av korruption men uppenbarligen ett sätt att sätta demokratin ur spel.
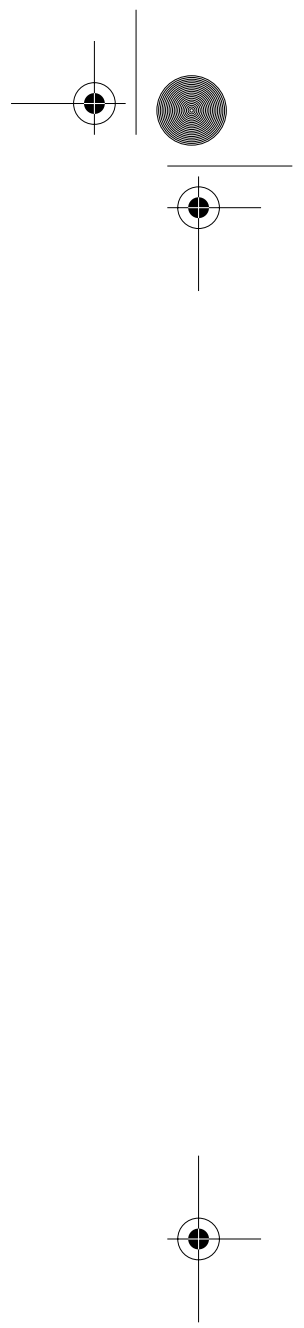
välbetalda befattningar inom näringslivet eller att statliga subventioner flödar till intresseorganisationer vilka stödjer vissa politiska intressen. En Världsbanksstudie noterar att företagsledare som tror att staten otillbörligt påverkas av en liten krets av «kompisar» i högre grad undanhåller skatt, betalar mutor och undviker domstolar. ${ }^{3}$ Detta handlande bidrar till att de statliga institutionerna förblir svaga. De riktigt stora företagen befinner sig ofta i en gynnad position, då de har direkttillgång till den högsta politiska ledningen.

(d) Intressekonflikter kan ha drag av korruption. Särskilt i den anglosaxiska världen vakar man inte bara över rent jäv utan också över bindningar av mer subtil karaktär. Nepotism är en form av intressekonflikt. Om en tjänsteman, som har ett personligt intresse av något slag $\mathrm{i}$ ett ärende, befattar sig med detta, kan det skada förtroendet för organisationen, även om hans intresse inte påverkar beslutet i ärendet. Så snart beslut kan påverkas av ovidkommande hänsyn påminner situationen om korruption, varför det är naturligt att intressekonflikter uppmärksammas inom ramen för korruptionsbekämpning. "Kompisinflytande» i en mer oskyldig form («old school tie») kan ses som en form av intressekonflikter. Sådana kan ha särskild betydelse i samband med att en offentlig tjänsteman eller en politiker går över till näringslivet, varför det har blivit allt vanligare att etiska riktlinjer utfärdas som bl. a. skall förhindra att en tjänsteman eller politiker fattar beslut som kan gynna en kommande arbetsgivare.

\section{Att avgränsa och definiera korruption}

\subsection{Behövs en definition?}

Det finns en uppsjö av definitioner och åtskilliga diskussioner och analyser av vilken definition som är «riktig» och mest ändamålsenlig. Korruption har kommit att bli ett samlingsbegrepp för en mängd klandervärda företeelser inom den offentliga sektorn. Det är troligen bara i ett straffrättsligt och straffprocessrättsligt sammanhang som det finns behov av en klar, entydig och avgränsad definition. I ett allmännare sammanhang - t. ex. vad gäller nationella strategier för att bekämpa korrup-

3 Joel S. Hellman \& Daniel Kaufmann, i: «The Inequality of Influence», i: János Kornai \& Susan Rose-Ackerman (red.), Building a Trustworthy State in Post-Socialist Transition, Palgrave, New York 2004, s. 100 ff.
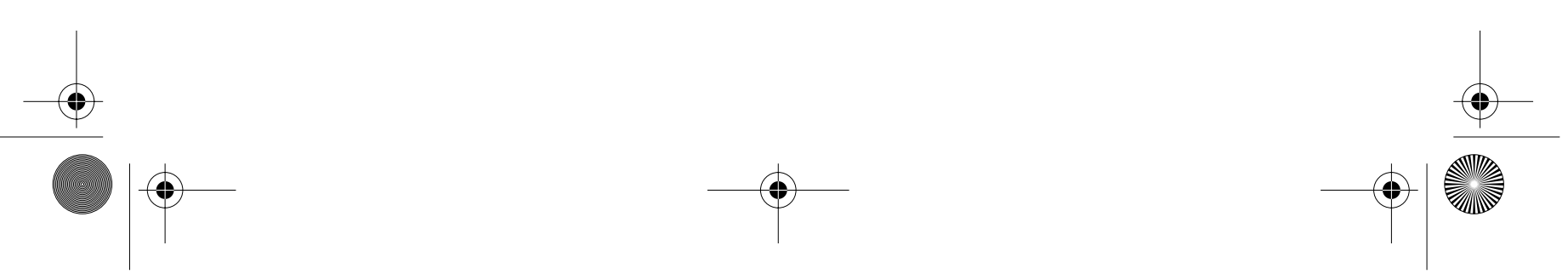
tion - kan det vara både tillfyllest och mest ändamålsenligt att ha en ganska öppen definition som inte nödvändigtvis gör skillnad mellan korruption och närliggande företeelser, t. ex. stöld eller förskingring av allmänna medel. Man kan också - vid sidan av det straffrättsliga begreppet - ha ett vidare begrepp för att bestämma arbetsområdet för ett specialorgan med uppgift att bekämpa korruption, något som kan ske på många andra sätt än på straffrättslig väg. Sådana organ ges vanligen ett brett uppdrag som en följd av att korruption ges en vid innebörd i detta sammanhang. Samtidigt kan det korruptionsbegrepp som används i strafflagstiftningen vara snävt i den mån som det över huvudtaget finns ett särskilt korruptionsbrott i denna. ${ }^{4}$

\subsection{Att avgränsa korruption}

TI, Världsbanken och andra använder ett brett begrepp: «the abuse of entrusted power for private gain» (TI) respektive «abuse of public power for private gain» (VB). Stort sett alla handlingar som en offentlig tjänsteman vidtar utgör alltså korruption i den mån som de gynnar tjänstemannen personligen på ett eller annat sätt. Ibland brukas också definitionen «abuse of power for private gain». Uppenbarligen blir definitionen då än vidare, eftersom den inbegriper tagande av otillbörliga förmåner också inom det privata näringslivet. TI:s och VB:s definitioner inbegriper missbruk till förmån för politiska syften, t. ex. gynnande av politiska partier eller sammanslutningar som står politiska partier nära. Korruption blir ett vitt begrepp på så sätt att inte bara bestickning och tagande av muta kan falla in under begreppet utan också andra former av missbruk, t. ex. bedrägeri, trolöshet mot huvudman och förskingring liksom gynnande av vissa intressen genom att jäv inte respekteras.

Internationella Handelskammaren gör skillnad mellan «bribery» (närmast «bestickning») och «extortion» (närmast «mutbrott»). Med det senare åsyftas följande: «The solicitation of bribes is the act of asking or enticing another to commit bribery. It becomes extortion when this de-

\footnotetext{
4 Bolivia är ett exempel på att flera begrepp brukas. Vietnam är ett exempel på att strafflagstiftningen har ett vitt begrepp. Bedrägeri och «trolöshet mot huvudman» (staten) betraktas som korruption. Detta brott kan för övrigt rendera dödsstraff. 2003 avrättades en vietnamesisk viceminister för att ha sålt statlig egendom men behållit intäkterna.
}
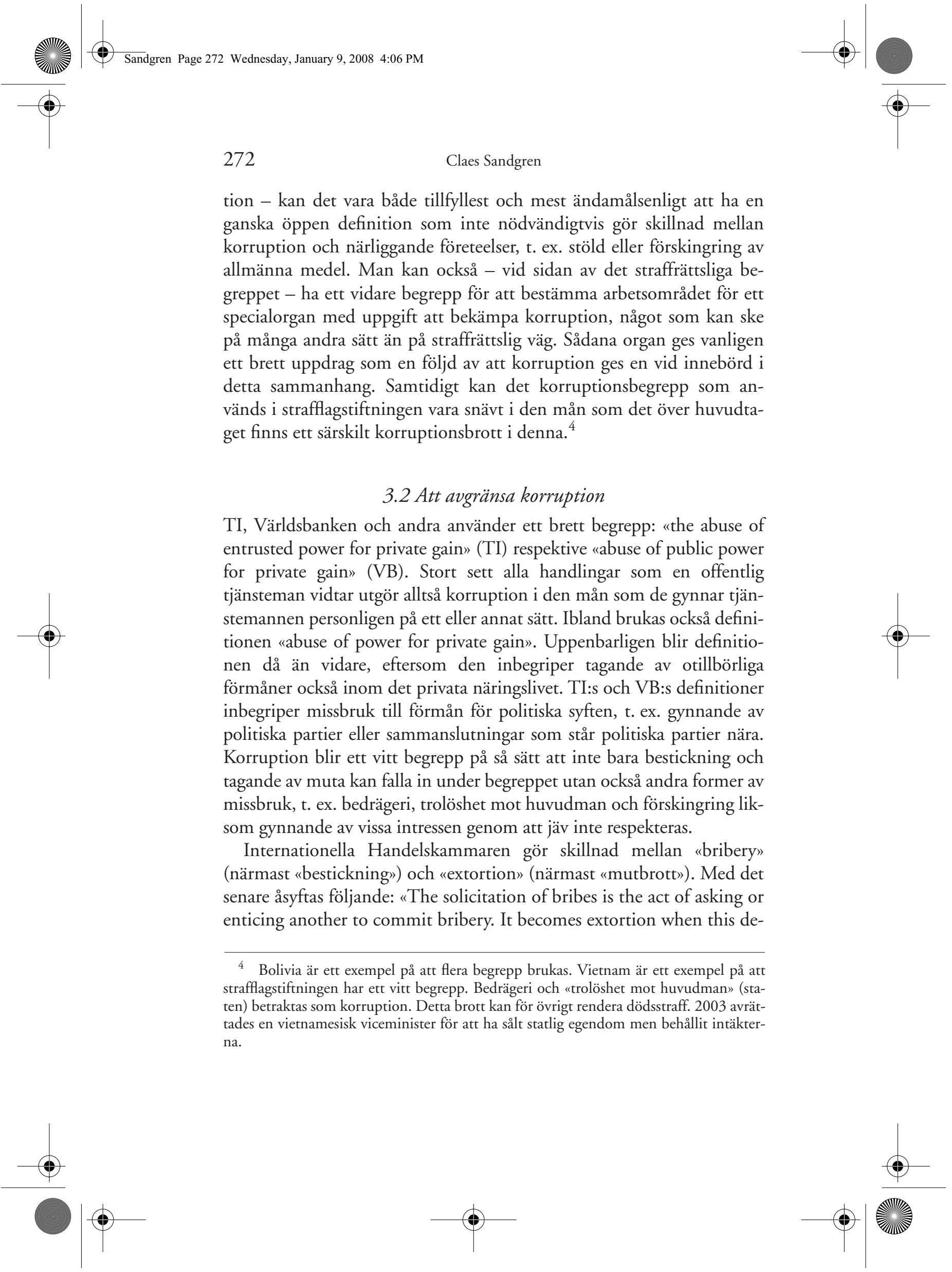
mand is accomplished by threats that endanger the personal integrity or the life of the private actors involved.»

\subsection{Korruptionens huvudelement}

Även om det alltså finns flera olika definitioner av korruption, så kan man urskilja ett antal rekvisit som brukar återfinnas i definitionerna.

I flertalet länder är det bara offentliga organ som omfattas av korruptionsbegreppet. ${ }^{5}$ Statliga företag, privata företag som bedriver offentligt reglerad verksamhet och helt privata företag kan omfattas, men vanligen jämställs inte tjänstemän $\mathrm{i}$ offentlig och privat verksamhet.

Med muta brukar åsyftas en fördel som lämnas eller mottas. En muta kan föreligga fastän den inte har syftet att påverka en person att i tjänsten handla på ett visst sätt. Men vanligen krävs att syftet är att påverka tjänstemannen att fatta ett beslut eller vidta annan åtgärd som gynnar den som besticker honom, alternativt lämnas mutan i efterhand som en belöning. Det förekommer att straffbarhet förutsätter att tjänstemannen beslutar i strid med sina tjänsteåligganden eller på annat sätt bryter mot en plikt i sin tjänsteutövning. Ett sådant krav är dock oklart till sin innebörd. Också om han beslutar på ett helt korrekt sätt - vare sig det gynnar eller missgynnar bestickaren - bör tjänstemannen rimligen göra sig skyldig till mutbrott. Om han har sin överordnades godkännande för sitt handlande föreligger det dock i vissa länder normalt inget tjänstefel.

Det krävs att tjänstemannen har eller kan få (personlig) vinning av transaktionen. Personlig vinning brukar tolkas vitt. Det kan vara tjänstemannen själv eller hans familj som gynnas. Men också en förmån för ett honom närstående intresse kan falla in under begreppet, t. ex. ett företag eller politiskt parti till vilka han har en bindning. Begreppet «vinning» («otillbörlig förmån») inbegriper ett vitt spektrum av förmåner och tjänster, t. ex. lån, hjälp av varjehanda slag, röster, inflytande, anställning, löften om framtida förmåner o.s.v. I många länder är det straffbart att taga emot en förmån också om denna inte kan åsättas något pekuniärt värde. Olika former av vänskapskorruption och nepotism kan här komma här in i bilden.

\footnotetext{
5 Såvitt gäller den ordning som vi har i Sverige så kan noteras att det är en relativt vid krets av personer som omfattas av «mutbrottet» (BrB 20:2); bl. a. inbegrips personer i enskild tjänst. $\AA$ andra sidan är bestickningsbrottet (BrB 17:7) relativt snävt avgränsat.
}
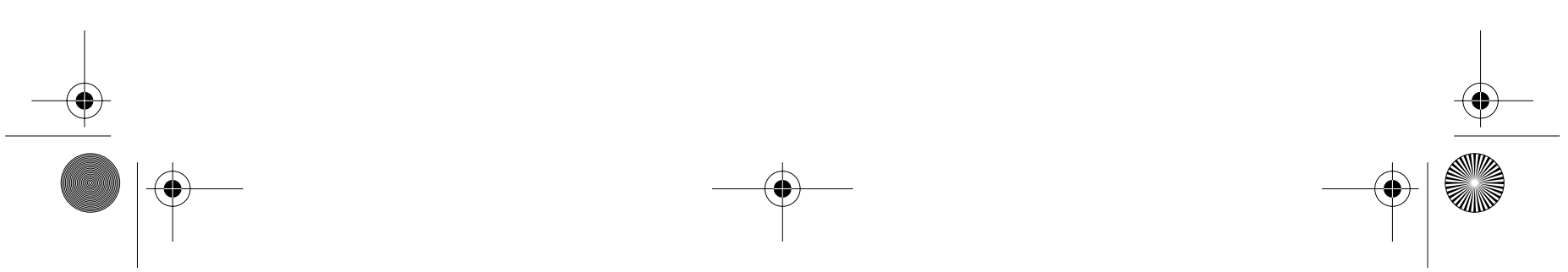
Ett annat kriterium är att transaktionen inte skall vara kutym. Också detta är ett svårhanterligt kriterium, eftersom det skulle kunna innebära att ett visst rutinartat missbruk av en befattning skulle kunna gå fritt, i vart fall vissa former av «petty corruption».

Ett kriterium är vidare att förmånens värde inte skall vara ringa. I många rättsordningar är alltså beloppets försumbarhet en godtagbar invändning. Om å andra sidan en tjänsteman många gånger per dag uppbär en liten penningsumma, kan detta ligga vid sidan av det tillbörliga. Också här växlar förhållandena från ett land till ett annat.

Korruption är vanligen en aktivitet som hålls hemlig. Bestickning $i$ samband med en upphandling är ett typiskt exempel. Men det kan förekomma att bestickning sker öppet. Ett exempel är att bidrag till politiska partier lämnas öppet också för det fall det görs i former som gör dem till bestickning, t. ex. bidrag är förenade med klara villkor för det kommande regerandet. Ett annat är att tjänstemän bjuds på lyxkonsumtion. Att detta sker öppet utesluter inte att det rör sig om korruption.

Det vanligaste torde vara att korruptionen är påtvingad den som besticker, t. ex. en polis eller tulltjänsteman som kräver en muta för en tjänst. Men detta är inget kriterium. Ibland sker bestickningen i maskopi mellan de bägge parterna, t. ex. när en muta lämnas i samband med en upphandling.

Det kan till sist nämnas att man i många länder betecknar handlingar som korruption vilka kan ha också andra brottsrubriceringar, t. ex. trolöshet mot huvudman och förskingring.

\subsection{Gåvor}

Gåvor vållar stora problem, särskilt kanske i Asien och Afrika emedan det där finns en vitt spridd kultur av gåvor och gengåvor vilkas benefika karaktär kan vara mer eller mindre framträdande. Det finns många situationer där en gåva förväntas men där gåvan inte är helt och hållet benefik. Detta är en kutym som kan vara svår att bryta samtidigt som här kan finnas ett visst korrupt inslag.
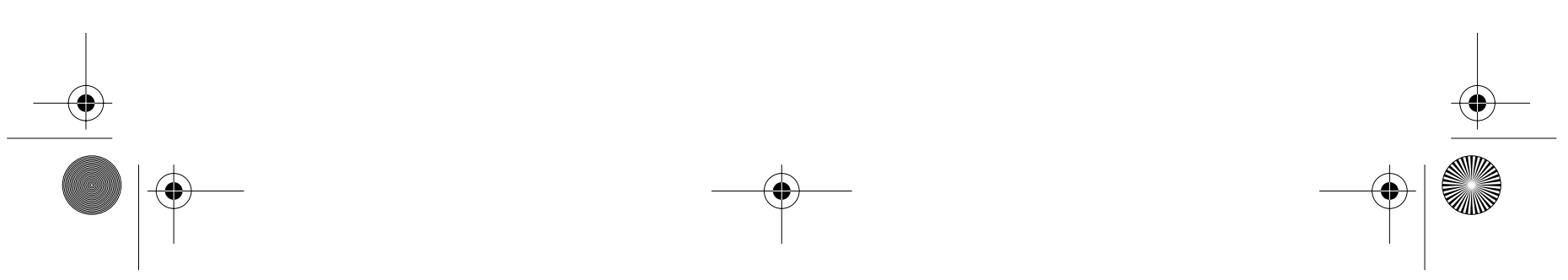


\subsection{Korruption inom näringslivet}

Privatanställdas missbruk av sin position i företaget för att berika sig betecknas vanligen inte som korruption. Här finns alltså en skillnad jämfört mellan offentlig och enskild tjänst. Skälet för skillnaden kan vara att en offentlig tjänstemans missbruk av sin ställning anses vara mer klandervärt därför att det skadar förtroendet för det allmänna. Ett annat skäl kan vara att allmän egendom anses mer skyddsvärd än enskild. Inget av skälen framstår som särskilt övertygande. Det senare argumentet torde delvis vara en rest från de socialistiska staterna där angrepp på statlig egendom ansågs och anses som ett angrepp på systemet. Det finns dock en tendens att också tagande av muta inom näringslivet förs in under mutbrottet i strafflagstiftningen. Den syn som råder i t. ex. Sverige tycks alltså få ökat genomslag i världen.

\subsection{Villkor som företag ställer}

Det är inte ovanligt att stora, transnationella företag ställer villkor på en stat för att företaget skall investera i landet. Villkor av detta slag vållar inte sällan kontroverser och kritik. Detta betecknas ibland som korruption («state capture»). Villkoret kan vara att regeringen skall införa eller ändra en viss lagstiftning, göra vissa investeringar (t. ex. i infrastruktur), sänka en viss skattesats, skapa en viss utbildning osv. Det kan kanske ibland likna en utpressningssituation men bör dock inte betecknas som korruption så länge som ingen på den statliga sidan har personligen vinning (i ovan nämnd mening) av företagets investering.

\section{Korruption, samhällsstyre och utveckling}

\subsection{Korruption och styresskick}

(a) Som framgick ökar korruption ojämlikheten, uppfattas som orättvis och skapar ineffektivitet. Vitt spridd korruption i ett demokratiskt styresskick undergräver därför stödet för demokratin men den urholkar legitimiteten också för ett enpartisystem. I t. ex. Kina och Vietnam är de styrande väl medvetna om detta och söker därför aktivt komma till rätta med korruptionen. Orsakssambandet är alltså här klart: korruption skadar en regims legitimitet oavsett vilket styresskicket är.
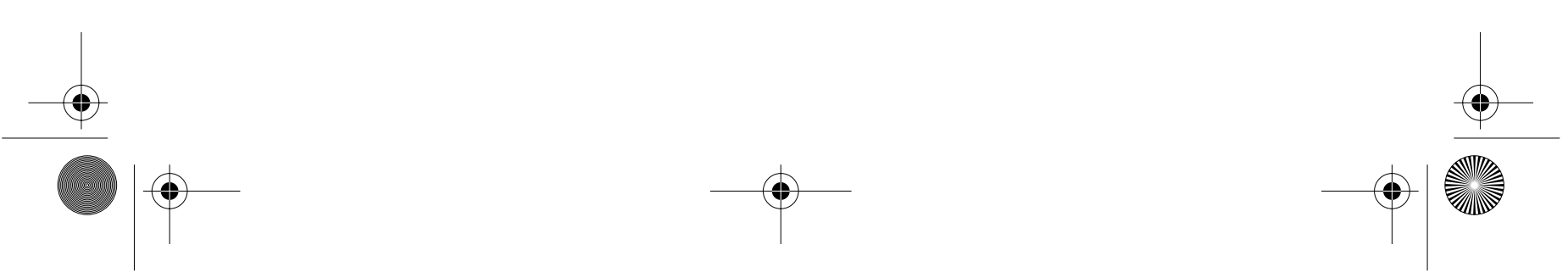
(b) Orsakssambandet i motsatt riktning är mindre klart. Det är svårt att finna att korruption skulle vara mindre frekvent i endera enpartistater eller demokratiska stater. Det saknas alltså belägg för att graden av demokrati skulle vara korrelerad med graden av korruption. Införs demokrati leder det alltså inte nödvändigtvis till en reduktion av korruptionen. Detta är dock - av flera skäl - något gåtfullt. En hög nivå av ekonomisk frihet och låg korruptionsnivå är nämligen korrelerade samtidigt som ekonomisk frihet typiskt sett frodas bäst i demokratier. Ett andra skäl är att det kan vara svårare att komma till rätta med korruption i enpartistater, eftersom «systemet är korrekt». Systemförändringar blir därför svårare att åstadkomma. Följden är att enskilda personer lastas för korruptionen och gärna ådöms mycket stränga straff, ibland dödsstraff, så som sker i Kina och Vietnam. Ses därmed straffrätten som främsta remedium, är utsikterna att nå framgång med korruptionsbekämpningen ringa. Det sagda hindrar dock inte att repressionen i enpartistater kan vara ett effektivt remedium mot korruption. Denna tycks ha ökat i länderna i forna Sovjetunionen efter enpartiväldets upplösning.

Låg institutionell kvalitet - såsom myndigheters bristande förmåga att fullgöra sina uppgifter - leder till att korruptionen uppfattas vara hög enligt både TI:s och WB:s index. Det räcker med att folk uppfattar korruptionen som hög för att systemet skall förlora i legitimitet och t. ex. skatteflykten öka och näringslivsklimatet påverkas. Här råder en stor skillnad mellan länder i syd och öst å ena sidan och OECD-länderna å den andra. I de förra uppges finansiering, korruption och byråkrati i nu nämnd ordning vara de svåraste hindren för att göra affärer. I OECDländerna är inte korruption något av de tre främsta hindren. Dessa är i stället i tur och ordning: arbetskraft, skattenivån och byråkrati. ${ }^{6}$

\subsection{Korruption och rättsväsende}

Det finns samband i bägge riktningarna mellan korruption och rättsväsende, dvs. ett svagt rättsväsende bäddar för korruption men denna senare försvagar också rättsväsendet.

6 Daniel Kaufmann, Governance Redux: the Empirical Challenge, World Bank Institute, www.worldbank.org/wbi/governance/pdf.
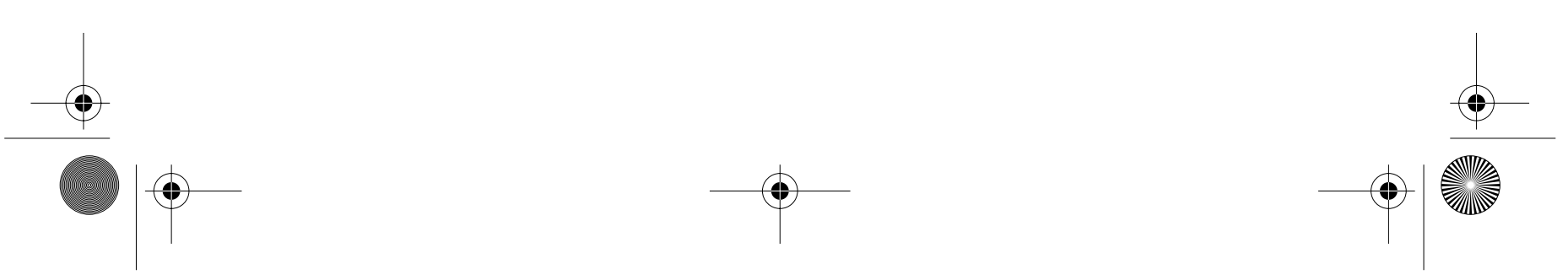
Ett svagt rättsväsende är nära förbundet med en informell ekonomi. Förekomsten av en stor informell ekonomi visar att det brister i statens förmåga att reglera och beskatta. Inte minst centralt är systemet för att göra det möjligt att starta och driva företag. Fungerar inte t. ex. bolagsregistrering, bolagsrätt, skyddet för egendom och avtalsgrundade rättigheter, skattelagstiftning, tvistelösning osv. på ett effektivt och opartiskt sätt växer det fram en informell ekonomi. Det innebär bl. a. att många företag inte kan få krediter och därför agerar «informellt». Det kan också uttryckas så att rättsväsendets oförmåga att sköta sina uppgifter driver företag in i ett olagligt beteende.

För att de informella relationer, som utgör stommen i en informell ekonomi, skall kunna bära upp affärstransaktionerna krävs ett stort mått av tillit mellan berörda parter, en tillit som delvis måste vila på privata sanktioner. Dessa räcker dock bara ett stycke. Gråzonen mellan illa fungerande officiella regler och institutioner å ena sidan och den informella rätten å den andra är gynnsam för korruption. Mutor behövs för att företag skall kunna etableras och affärsverksamhet kunna bedrivas. Är staten oförmögen att verkställa sina egna regler effektivt och opartiskt träder mutor och privat skydd i statens ställe, fastän företag hellre förlitar sig på officiella regler och institutioner. De föredrar också lagliga och opartiskt administrerade skatter framför de kostnader som följer med informaliteten. Denna kan aldrig ge samma fasta grund för verksamheten. Frånvaron av en stat som en tillförlitlig aktör hämmar investeringar och transaktioner.

\subsection{Korruption och utveckling}

Korruption bidrar till fattigdom på flera sätt. Rent allmänt sammanfaller hög korruptionsnivå med lägre nivå för investeringar och tillväxt liksom med lägre kapitalinflöde och lägre direktinvesteringar från utlandet. Det finns studier som visar att ett korrupt land kan antas ha en investeringsnivå som ligger $5 \%$ lägre än ett land som är relativt fritt från korruption, och förlora en tillväxt om $0,5 \%$ årligen. Att investera i ett korrupt land kostar $20 \%$ mer i form av en «privat skatt». Enligt en studie skulle Pakistan kunna höja sin BNP-tillväxt med $2 \%$ om landet hade haft en korruption på samma nivå som Singapore. Investeringarna i Indien skulle ligga på en 12 \% högre nivå om landet hade en korrup-
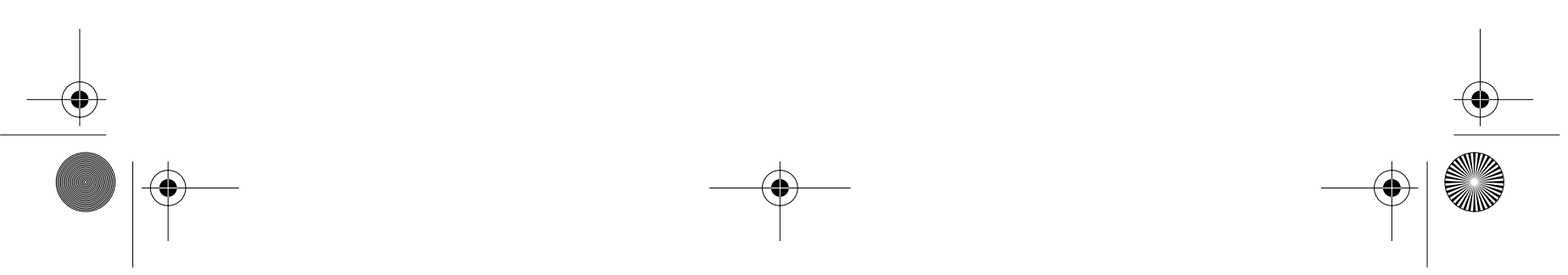
tion på skandinavisk nivå. ${ }^{7}$ Korruption sänker produktiviteten, minskar effektiviteten i näringspolitiken och uppmuntrar företagen att verka i den informella sektorn i strid med skatte- och annan lagstiftning.

\subsection{Korruption, terrorism och organiserad brottslighet}

Som redan berörts (1.8 ovan) har de ökade ansträngningarna att bekämpa terrorism och organiserad brottslighet riktat uppmärksamheten mot korruption inom såväl de brottsbekämpande instanserna som domstolarna. Organiserad brottslighet hotar i synnerhet svaga stater, inte minst stater som saknar ett starkt rättssystem. Sådana stater har liten motståndskraft mot organiserad brottslighet. Organiserad brottslighet försvagar också staten bl. a. därför att de som bedriver sådan brottslighet har resurser att ägna sig åt storskalig korruption och behov av att besticka rättsväsendets funktionärer. Också här finns alltså ett samband i bägge riktningar.

\subsection{Korruption och sårbarhet}

Det finns ett samband mellan korruption och sårbarhet. Korruption kan leda till att normer för säkerhet och hälsa inte iakttas, att byggnormer inte iakttas, att mark inte brukas enligt gällande föreskrifter, att hastighetsföreskrifter inte respekteras på transportområdet, att politiskt ansvar inte krävs ut, att vårdslöshet inte utreds och lagförs osv. Alla dessa slag av försummelser kan hänga samman med att mutor utbetalas för att kostnader skall undvikas, tid vinnas, ansvar undgås eller någon annan fördel uppnås.

Det ligger i sakens natur att återuppbyggnad och annat arbete efter en katastrof bedrivs i en ofta kaotisk och svårkontrollerad miljö, som är en grogrund för korruption och allehanda brottslighet. Stora mängder av varor skall upphandlas och levereras under en kort tidsperiod. Också samordningsproblemen är osedvanligt svårbemästrade. Det finns därför behov av särskilda kontrollmekanismer. Inte minst kan enskilda organi-

7 Se Daniel Kaufmann, «Anticorruption Strategies: Starting Afresh? Unconventional Lessons from Comparative Analysis», i: Rick Stapenhurst og Sahr J. Kpundeh (red.), Curbing Corruption. Toward a Model for Building National Integrity, The World Bank, Washington D.C. 1999, s. 45 f.
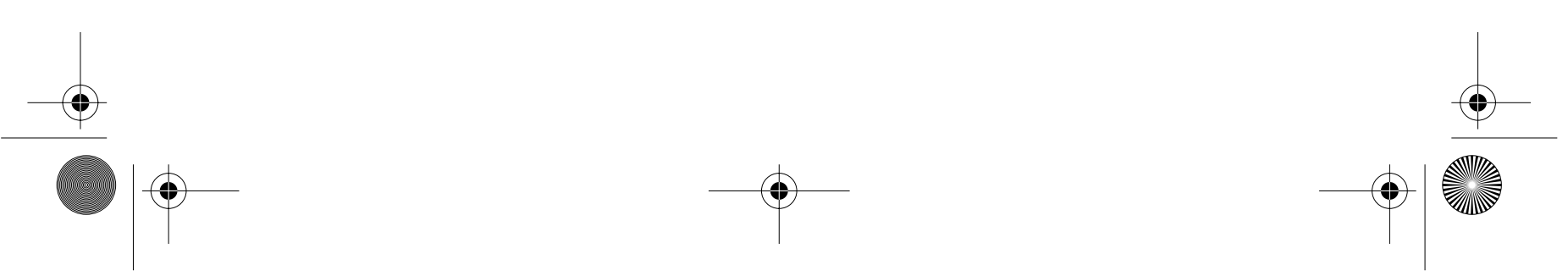
sationer spela en betydelsefull roll för kontrollen. Biståndet bör också utformas så att lokalt ansvarstagande uppmuntras och lokala materiel brukas. $\AA$ andra sidan kan det inte uteslutas att en katastrof av de dimensioner som utmärkte tsunamin i Sydostasien kan mobilisera befolkningen till att kraftfullt ingripa mot korrupt beteende. Det återstår att se om en sådan gynnsam effekt kommer att uppstå i de berörda länderna, av vilka särskilt Indonesien är känt för omfattande korruption.

\section{Orsaker till korruption}

\subsection{Korruption och sambällsstyre}

(a) Korrupta länder har ofta en svag och överansträngd stat, nämligen en stat som inte förmår att fullgöra sina grundläggande funktioner, inklusive att upprätthålla rättssamhället eller kontrollera sina tjänstemän. Till statens svaghet hör att den i många fall tagit på sig alltför många uppgifter, t. ex. att driva stora företag. Av detta följer att svaret på korruptionen inte kan vara att försvaga staten; tvärtom bör den stärkas så att den förmår fullgöra sina uppgifter. En annan sak är att dessa möjligen skall reduceras så att staten koncentrerar sig på sina grundläggande funktioner.

(b) En annan iakttagelse är att korrupta stater i många fall utmärks av toppstyrning och maktkoncentration. Häri ligger att invånarna i allmänhet har litet reellt inflytande, dvs. det brister i folkligt deltagande, folklig insyn, maktdelning, möjlighet till ansvarsutkrävande och liknande faktorer som skapar delaktighet och inflytande.

Den gemensamma nämnaren för (a) och (b) kan sägas vara brister i samhällsstyret.Den iakttagelsen pekar också i vilken en riktning som en lösning skall sökas, men inte mycket mer än så. Ty att förbättra samhällsstyret är en så gigantisk uppgift att man gärna går vilse om man är överambitiös.

\subsection{Direkta och indirekta orsaker}

Det är skäl att söka systematisera orsakerna till korruption och identifiera de grundläggande orsakerna för att på så vis fă ledning för arbetet med att angripa korruptionen. Man kan lämpligen skilja mellan direkta
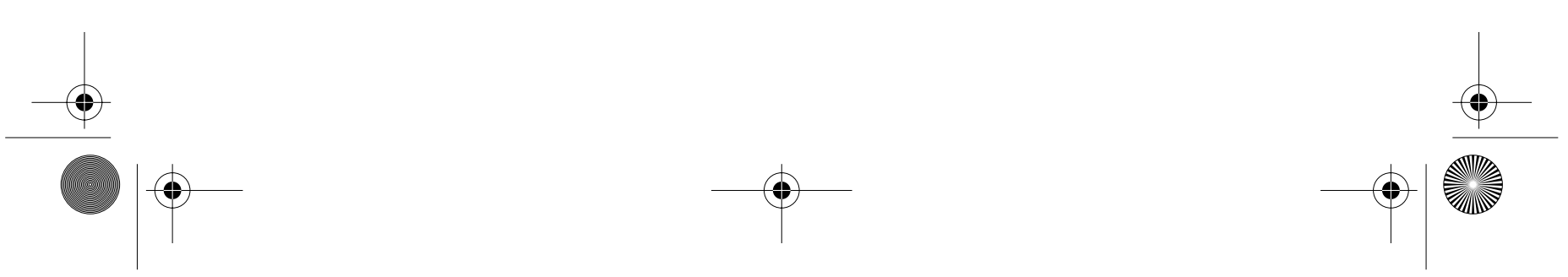
och indirekta orsaker. Direkta orsaker innebär att tillfällen till korruption erbjuds:

- Statliga monopol.

- Regleringar och tillståndsgivning, till exempel tillstånd för export och import och byggnadstillstånd.

- Beslut om statliga utgifter, t. ex. beslut att göra statliga investeringar, upphandlingar och liknande.

- Tillhandahållande av offentligt subventionerade varor och tjänster, t. ex. krediter, samhällstjänster, bostäder m. m.

Vissa aktiviteter kan sägas skapa en grogrund för korruption. Privatisering är ett tydligt exempel. $\AA$ andra sidan är effekten av privatisering på längre sikt att statliga monopol avlägsnas vilket erfarenhetsmässigt reducerar möjligheterna till korruption.

Indirekta omständigheter underlättar korruption:

- Byråkratiska traditioner, t. ex. rekrytering och befordran av tjänstemän på godtyckliga grunder, inte på meriter.

- Lönenivån.

- Sanktionssystem i form av otillräckliga straff eller disciplinära åtgärder liksom låg upptäcktsrisk; det kan röra sig om brister både i lagstiftningen och hos de tillämpande organen.

- Bristande öppenhet hos myndigheter och regelsystem.

- Utrymme för godtyckliga beslut ger möjligheter för en tjänsteman att fritt besluta; det kan vara en lärare som sätter betyg, en tjänsteman som skall meddela ett tillstånd eller en läkare som skall bestämma vilken patient som skall ges förtur.

- Svagt ledarskap. Det kan bestå i att ledningen är besticklig men också däri att den inte föregår med gott exempel för personalen.

- Brister i ansvarsutkrävandet.

- Mycket direktkontakter mellan tjänstemän och allmänheten.

Denna förteckning är långt ifrån fullständig. Den är en erinran om att möjligheter till korruption alltid kommer att finnas, eftersom i stort sett alla de företeelser som här berörts förekommer i alla samhällen i större
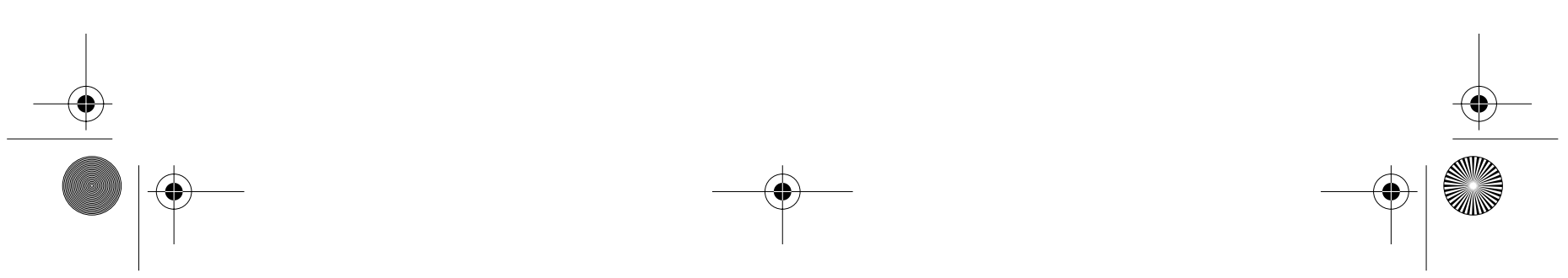
eller mindre utsträckning. Det behövs en konstant vakthållning vid gränsen mot det otillåtna.

\subsection{Ekonomiska, institutionella och rättsliga orsaker}

En annan indelning än den just nämnda är att hålla i sär ekonomiska, institutionella och rättsliga orsaker till korruption. Tanken skulle vara att ett program för att bekämpa korruption bör gå fram på olika fronter. Detta låter förnuftigt men visar sig inte vara alldeles lätt. Klassificeringen beror i mångt och mycket på det perspektiv som anläggs. En reglering kan uppfattas som en ekonomisk, institutionell eller rättslig orsak till korruption liksom en och samma reform kan betecknas som både ekonomisk, institutionell och rättslig.

Ekonomer brukar peka på att orsakerna till korruption i första hand skall sökas i den ekonomiska politiken och att prioritet därför bör ges åt åtgärder som ändrar denna politik. Exempel på ekonomisk politik som skapar en grogrund för korruption är som nämnts överreglering, statliga monopol, statliga företag, ekonomier som är stängda mot omvärlden och statliga subventioner. Ekonomer brukar särskilt framhålla att reglering av näringslivet och intervention i affärsförhållanden leder till ökad korruption.

Som institutionella orsaker kan nämnas svag rättsstat, svagt egendomsskydd, låg grad av professionalism inom förvaltningen, låga löner och svaga incitament också i övrigt inom förvaltningen, bristande öppenhet, svagt ansvarsutkrävande $\mathrm{m}$. $\mathrm{m}$. De institutionella orsakerna hänger samman med de ekonomiska redan därför att ekonomiska reformer brukar stärka de krafter som verkar för institutionella reformer.

Det torde framgå av det här sagda att många av de reformer som kan bli aktuella kan betecknas som rättsliga lika väl som ekonomiska eller institutionella.

\section{Strategier för att bekämpa korruption}

\subsection{Några utgångspunkter och framgångsfaktorer}

Korrupta samhällen lider av brister i samhällsstyret. På ett allmänt plan är det därför lätt att ange i vilken riktning man skall gå för att bekämpa korruption: ett riktmärke är väl fungerande samhällen där korruptionen 
definitionsmässigt är begränsad. Att försvaga statens organ är däremot ingen framkomlig väg. Ett land som har oberoende domstolar har bättre utsikter att bekämpa korruption än en svag rättsstat. Huvudfrågan blir därför: hur kan svaga stater få till stånd grundläggande förändringar av samhällsstyret i önskvärd riktning, t. ex. i riktning mot öppenhet, kontroll och spridning av makten, medborgerligt inflytande, medborgerlig tillit till statliga institutioner o.s.v.?

Här finns inneboende svårigheter. Korruption hindrar eller försvårar önskvärda reformer. Ett skäl är att de organ som är satta att bekämpa korruption själva kan vara anstuckna. Härtill kommer att många reformer som är behövliga per se, t. ex. avreglering liksom privatisering av förlustbringande företag, har som sidoeffekter att möjligheterna till korruption minskas. Starka intressen motverkar därför sådana reformer. Här finns en paradox; staten skall bekämpa sig själv.

En nyckelfaktor är acceptansen i samhället för korruption. Man bör därför söka påverka medborgarnas attityder och agerande. Om de kraftigt motsätter sig korruption underlättas arbetet väsentligt. För det krävs emellertid att de har kunskap om korruptionens skadeverkningar och att de har makt att agera. Det behövs alltså folkbildning liksom kanaler för inflytande, klagomål och kontroll.

Det krävs ett ledarskap som markerar att korruption inte är godtagbar och som i handling visar att man menar allvar. Korruption i ett lands toppskick smittar av sig. Strategier bör inte bara ha stöd från ett lands ledning utan bör också omfatta denna. Det behövs även möjligheter att utkräva ansvar av eliten när den gör sig skyldig till korruption. Ledningens stöd och engagemang är alltså erforderliga för en framgångsrik korruptionsbekämpning.

Ett stort antal utvecklingsinstitutioner och andra organisationer har utarbetat strategier eller liknande dokument. Här kan nämnas DFID (UK), EU, Finnida, GTZ (Tyskland), IDB, NORAD (Norge), OECD, TI, UNDP, USAID och Världsbanken. Även FN-systemet har särskilda strategiprogram riktade mot korruption, främst «Global Programme Against Corruption» (CPAC). Det finns stora skillnader i detaljerna mellan strategierna men de utgår från de faktorer som här berörts. ${ }^{8}$

8 Strategierna redovisas ingående av J.Anger, Antikorruptionsstrategier i utvecklingssamarbetet, Sida, januari 2004.
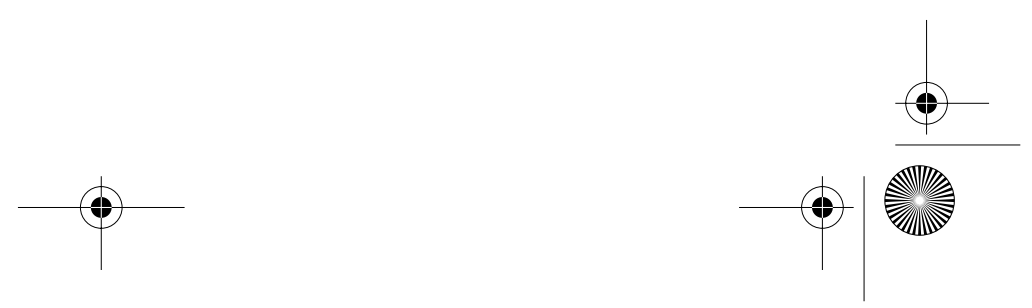


\subsection{Vad bör göras?}

Det är inte vare sig meningsfullt eller möjligt att skriva ut ett färdigt recept för vad som bör göras för att man skall kunna angripa korruptionen. Åtgärdsprogram bör vara landspecifika. Det går dock att peka på ett antal områden som typiskt sett är väl ägnade för åtgärder.

(a) Vissa tänkbara ändringar kan hänföras till den ekonomiska politiken. Hit kan räknas avreglering, öppning av ekonomin, ökad konkurrens, privatiseringar, moderniserad budgetprocess och förbättrad ekonomistyrning samt lönereform. En bristande balans mellan utbud och efterfrågan skapar möjligheter till korruption. Behovet av de regleringar, monopol, subventioner och liknande som skapar möjlighet till korruption bör därför omprövas. Reglering som gör marknadsinträde och verksamhet kostsamma bör ses över samtidigt som det bör hållas i minnet att många regleringar har goda skäl för sig; de behövs om man inte vill nöja sig med en nattväktarstat.

(b) Andra åtgärder avser närmast institutionell och rättslig reform. Detta kan omfatta förstärkning av rättsstaten, maktdelning, ökad professionalism inom förvaltningen, ökad öppenhet, garantier för en oberoende press, reform av skatteväsendet o.s.v. Reglering av bidrag till politiska partier kan också ingå i detta. Decentralisering är en typ av institutionell reform som typiskt sett underlättar bekämpning av korruption. Beslut förläggs närmare befolkningen och det blir lättare för denna att kontrollera användningen av offentliga medel.

I princip bör åtgärder riktas mot institutioner, snarare än individer. Ett sådant fokus på institutioner står dock inte nödvändigtvis i motsättning till att individer lagförs. Ställs ledningen för en institution till ansvar kan detta ge signaler till hela institutionen som påverkar attityder och arbetssätt inom denna.

(c) Korruption frodas i slutna rum. Öppenhet och insyn är därför centrala. Hit kan hänföras krav på handlingars och förhandlingars offentlighet inom offentliga organ. Öppenhet i fråga om politikers och tjänstemäns löner och övriga inkomster samt förmögenhet är en annan aspekt. Det kan också krävas att politiker och tjänstemän öppet redovisar bindningar och därmed intressekonflikter som kan äventyra deras oväld i tjänsteutövningen. Bidrag till politiska partier bör också vara offentliga, i vart fall om de överstiger ett visst belopp.
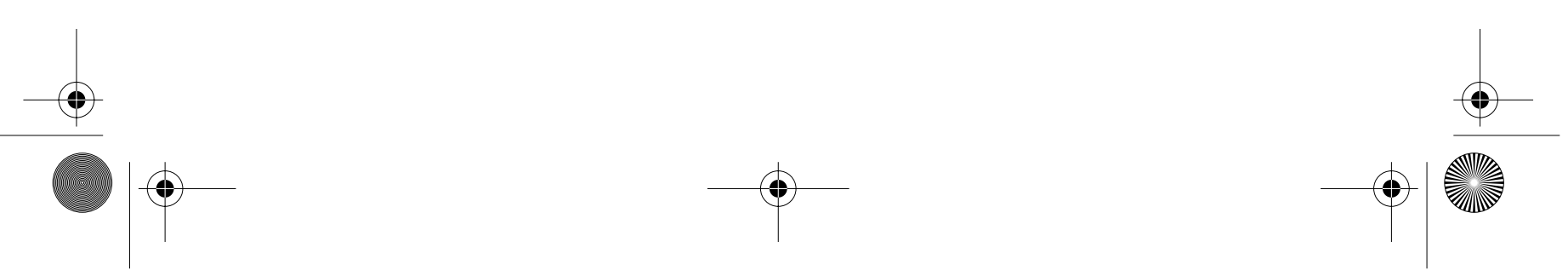
Tillgång till handlingar i upphandlingsförfaranden och en öppen redovisning av bedömningarna i sådana ärenden hör också hit. Detsamma gäller tillsättningen av offentliga tjänster och befordran av offentliga tjänstemän. Självständiga media och frihet från censur liksom ett obundet civilt samhälle är två andra pelare i ett öppet samhälle, liksom uppmuntran av kritik och debatt. Också intern kritik bör tillåtas, dvs. interna sanningssägare bör ges skydd mot repressalier från sin arbetsgivare. Även vissa tekniska reformer kan övervägas; exempel är utnyttjandet av Internet i samband med upphandlingar. Tekniska hjälpmedel kan öka öppenheten och motverka godtycke.

Med tanke på att utvinningen av olja, gas och mineraler ger mycket betydande och svårkontrollerade betalningsströmmar till länder i syd och öst i form av skatter och avgifter är en öppen redovisning av dessa betalningsströmmar angelägen. En sådan redovisning skulle underlätta för medborgarna i dessa länder att kontrollera hur dessa intäkter används. Ett initiativ har tagits av organisationen Publish What you Pay för att få till stånd en internationell regim som föreskriver att internationellt verksamma företag gör en sådan redovisning. Ett liknande syfte har ett initiativ benämnt «Extractive Industries Transparency Initiative» (EITI), vilket kräver redovisning också från mottagarsidan, något som skulle medge en jämförelse av de belopp som företagen respektive staterna rapporterade (jfr 1.6).

(d) Kontroll, ansvarsutkrävande och medborgerligt deltagande är också ett centralt område vilket för övrigt hänger nära samman med öppenhet. Det kan här handla om allt från korrekta val och kontrollorgan till åtgärder på det lokala planet. Exempel är att hushåll kan rapportera om missbruk av pengar avsedda för samhällstjänster. Lokalt verksamma personer och organisationer kan själva tillhandahålla samhällstjänster enligt kontrakt. Öppenhet och publicitet är starka medel om de kombineras med gräsrotsorganisationer som har incitament och kompetens att använda informationen.

Den offentliga upphandlingen bör ges särskild uppmärksamhet därför att det här rör sig om så stora summor och möjligheter för korruption. Det kan gälla stora infrastrukturprojekt men också koncessioner för utvinning av olja och mineraler. Företag kan ha legitima skäl att bruka agenter för uppdrag av detta slag men i många fall döljs bestickning genom bruk av sådana mellanmän.
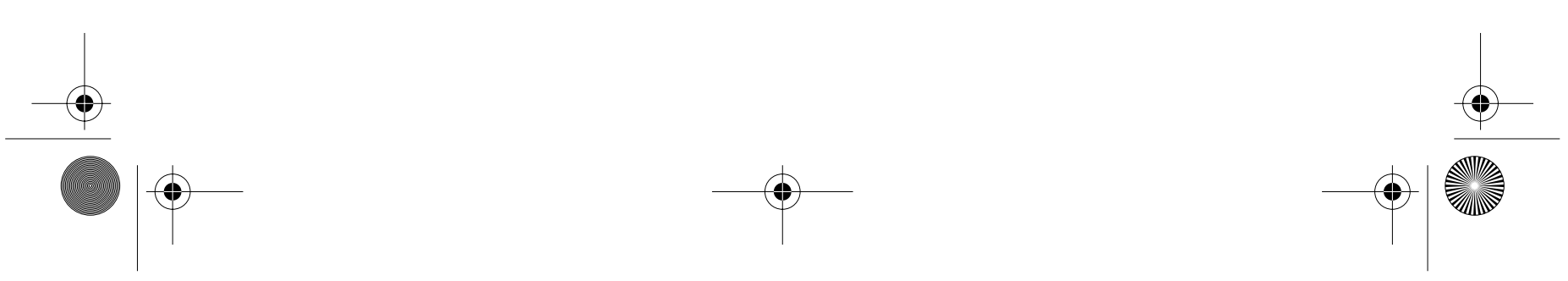
(e) Som nämnts går den informella sektorn hand i hand med omfattande korruption. Att eliminera hinder för en övergång till den formella sektorn kan därför vara viktigt inte bara för att ge dem som verkar informellt ökad trygghet och tillgång till sociala system utan även för att minska basen för korruption.

(f) Ett handlingsområde är slutligen bruket av ny teknik och nya metoder för att kartlägga och kontrollera korrupt beteende. Jämförelser mellan affärsenheter, företag, sektorer och länder ger underlag för att spåra korruption. IT-system har visat sig vara kraftfulla hjälpmedel för det arbetet.

\subsection{Utbudssidan}

Strategier och åtgärdsprogram av det slag som skissats här tar i första hand sikte på förhållandena i syd och öst. Det är naturligt att biståndsgivare anlägger ett sådant perspektiv. Det bör dock hållas i minnet att mycket av «grand corruption» har sina rötter i industriländerna. Det gäller inte minst korruption i förbindelse med vapenförsäljning liksom utvinning av olja, gas och mineraler. Skall korruptionsbekämpningen nå framgång är det därför önskvärt att åtgärder inkluderas som tar sikte på utbudssidan. OECD- och FN-konventionerna har en sådan inriktning. Det finns också organisationer - såsom brittiska DFID och TI som betonar ett sådant synsätt.

\section{Närmare om rättssystemets roll}

\subsection{Juridiska regelverk och institutioner}

För jurister är det sannolikt straffrättsliga remedier som kommer i tankarna när man resonerar om medel för att bekämpa korruption. Det kan därför förvåna en jurist att de erfarenheter och strategier som redovisats i det föregående bereder relativt litet utrymme åt det juridiska regelverket och de juridiska organen. Man kan förledas tro att dessa har en marginell roll att spela i korruptionsbekämpningen. Av flera skäl är dock en sådan slutsats förhastad.

Många av de åtgärder som berörts i det föregående behöver s.a.s. stöd från det juridiska systemet för att få effekt. Exempel är åtgärder som
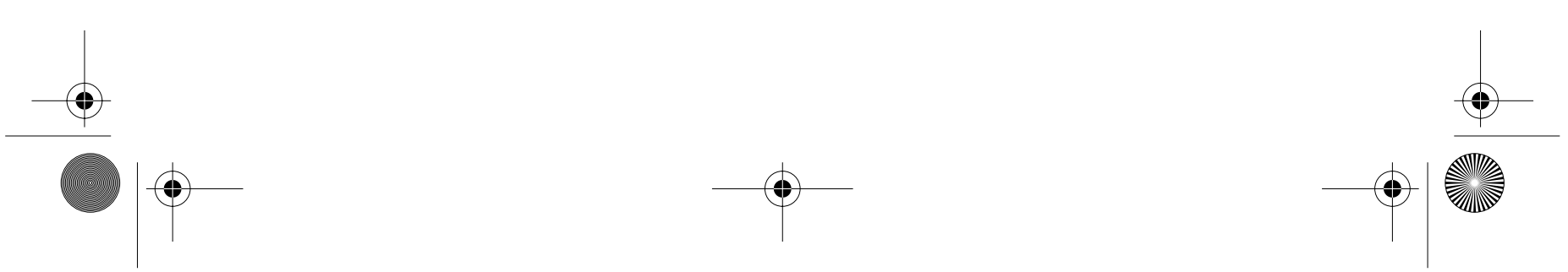
syftar till avreglering, privatisering, marknadstillträde, kontroll av makthavare, öppenhet, möjlighet för media och enskilda organisationer att agera, tillgång till Internet, protester o.s.v. Över huvudtaget är det svårt - och inte särskilt meningsfullt - att göra boskillnad mellan juridiska åtgärder och andra. Juridiken fungerar som ett kitt som håller samman samhällsstrukturen och är en förutsättning för ett «gott samhällsstyre». En mängd rättsliga institut och institutioner motverkar korruption utan att detta är deras uttalade syfte. Exempel är reglerna om handlingars offentlighet, regler om offentlig upphandling, regler som säkerställer massmediers oberoende ställning, friheten att etablera företag, konstitutionella regler om maktdelning och ansvarsutkrävande, straffprocessuella regler o.s.v. En effektiv konkurslagstiftning t. ex. kan vara en förutsättning för en omstrukturering av den statliga företagssektorn, vilken i många länder är förlustbringande och en härd för korruption.

Företräde bör ges åt systeminriktade insatser, dvs. sådana som stärker berörda institutioner och främjar öppenhet och annan god förvaltningskultur inom dessa. Det betyder att kontrollen av institutioners internkontroll är av största betydelse. Till internkontroll kan hänföras internrevisorer, granskare på lägre nivå och interna «sanningssägare».

En allmänt sett god rättskultur och ett rättssamhälle av hög integritet motverkar korruption. Exempelvis är det väl belagt att s. k. «state capture» $\mathrm{i}$ betydande grad utlöses av svagt skydd för äganderätt och kontraktuella rättigheter. $\mathrm{Om}$ företag inte kan lita på sina rättigheter av detta slag, frestas de att söka tillgodose sina intressen på annat sätt.

Strategier mot korruption måste beakta att korruption inom de brottsbekämpande organen - polis, tull, kustbevakning, skatteförvaltning m. fl. - liksom inom institutioner som övervakar dessa organ är särskilt förödande för korruptionsbekämpningens effektivitet. Detsamma kan sägas om de judiciella instanser som skall vara den yttersta garanten för att rättvisa skipas, t. ex. så att den som förfördelats skall kunna få sin rätt och den som åtalats inte skall kunna köpa sig fri. Man kan inte förvänta sig att allmänheten skall ta avstånd från korruption eller att illa avlönade tjänstemän skall avstå från mutor med mindre de hyser tillit till statens korruptionsbekämpning och ser resultat av denna.

Här bör inte minst skatteförvaltningens betydelse för korruptionsbekämpningen nämnas. Som betonats är korruption ett utflöde av en svag stat och ett illa fungerande samhällsstyre. Dessa brister är i sin tur
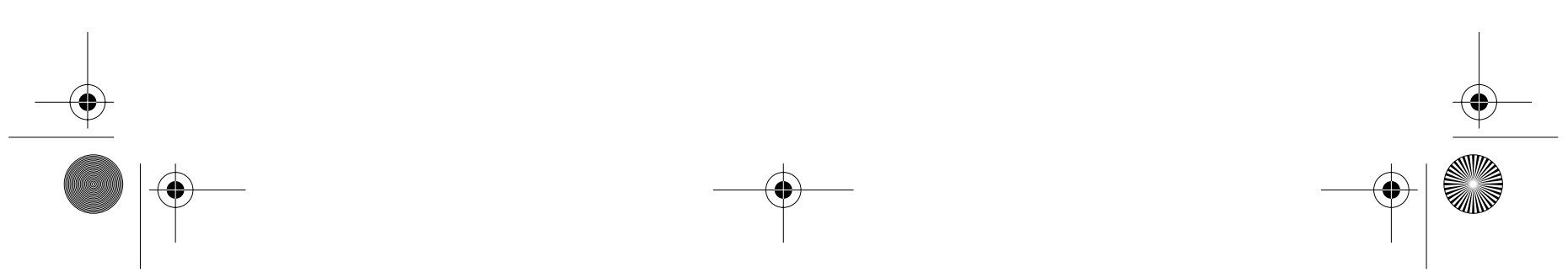
avhängiga av otillräckliga resurser för staten. Ökade skatteintäkter är en nyckelfråga för korruptionsbekämpningen. Det kräver att skatteförvaltningen är fri från korruption och bedriver skatteuppbörden på ett effektivt sätt. Bara så kan fiscus åtnjuta medborgerligt förtroende och lojalitet. Ytterst krävs naturligtvis också att de skatteintäkter som staten erhåller används väl och för ändamål som medborgarna godtar. Det är en förutsättning för att de skattskyldiga skall vara lojala som skattebetalare. Det som här sagts om skatteförvaltningen gäller i viss grad också tullen.

Det bör hållas i minnet att många av de grundläggande förhållanden som gör korruption möjlig inte kan avlägsnas, hur önskvärt det än vore från ett snävt teoretiskt-ekonomiskt perspektiv. Hit hör regleringar av näringslivet, stora offentliga upphandlingar, statliga monopol, statliga subventioner liksom skatter, tullar och avgifter. Ingrepp kan göras i dessa i större eller mindre utsträckning men det finns en klar gräns som hänger samman med den grundläggande politik som en regering vill föra så länge den inte vill nöja sig med en nattväktarstat. Det kommer därför alltid att finnas möjligheter för korruption, varför det behövs en offentlig övervakning och offentliga korrektiv samt organ som sköter detta. Det är tänkvärt att de renaste länderna i världen, inklusive de nordiska, inte alls är de där möjligheterna till korruption är små, tvärtom.

\subsection{Närmare om straffrätten}

Många dokument om korruptionsbekämpning ägnar de brottsbekämpande organen ganska ringa uppmärksamhet. Det hänger bland annat samman med att man vill angripa grundorsakerna och att man förordar en systemansats vilket innebär att man inte ser det meningsfullt att rikta uppmärksamheten mot individer. Detta synsätt är kanske i grunden sunt men framstår ändå som något verklighetsfrämmande.

Korruption alstras i miljöer där incitamenten är starka för ett korrupt beteende; det betyder att vinsterna av korruption är stora i relation till kostnaden. Denna senare kan i vart fall höjas om riskerna för upptäckt och straff höjs. Korruption av tvångskaraktär («extortive corruption») är lättare att upptäcka än korruption som bedrivs i samförstånd, t. ex. bestickning i samband med en anbudstävlan. Det är särskilt viktigt att korrupta personer på hög nivå lagförs. Detta kan ses som rättssamhällets
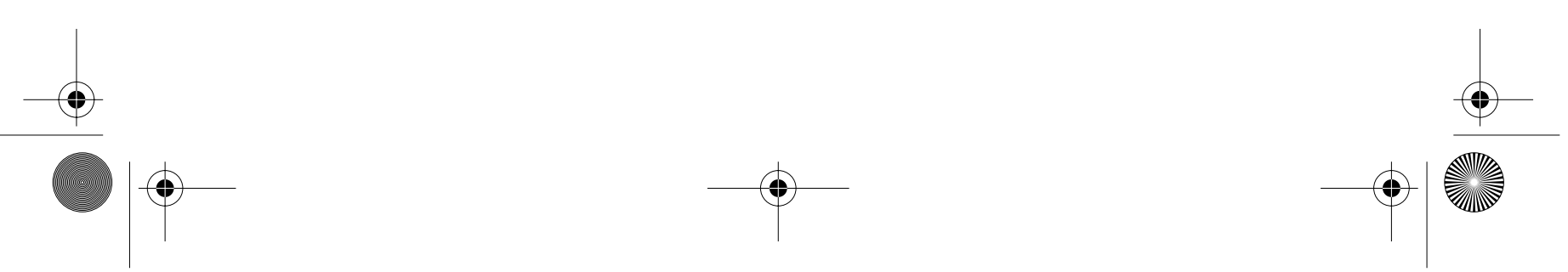
spjutspets riktad mot korruption. Men det har stor betydelse att klagomål mot personer på alla nivåer utreds och leder till rättsliga åtgärder när det är befogat. I annat fall urholkas medborgarnas stöd för arbetet att bekämpa korruptionen. Slutsatsen är att straffrätten och de brottsbekämpande organen har en viktig funktion att fylla trots sin inriktning på individer snarare än institutioner.

Alldeles särskild betydelse kan det ha att straffa personer som är ansvariga för att kontrollfunktioner inte upprätthålls. Det kan vara chefen för en institution som inte sett till att kontrollsystemet fungerar liksom revisorer och andra kontrollinstanser som varit försumliga. Om sådana personer lagförs för försumligheter, innebär det att s.a.s. individorienterade straffåtgärder vidtas till stöd för hela institutionens funktionssätt.

\subsection{Internationella överenskommelser och internationellt samarbete}

Den ökade vikt som tillmäts korruptionsbekämpning kommer till uttryck på det internationella normativa området i form av några konventioner. Här kan nämnas den konvention från 1997 som OECD antagit, "Convention on Combating Bribery of Foreign Public Officials in International Business Transactions». Konventionen, som trädde i kraft 1999, tar sikte på utbudssidan. Den innebär ett åläggande att straffbelägga och lagföra bestickning (men inte tagande av muta) av utländska offentliga tjänstemän och politiker i internationella affärsrelationer. Konventionen har hittills haft ganska få konkreta resultat men konventionsstaternas genomförande av konventionen är föremål för en ingående granskning som bör ge resultat på sikt.

Vidare kan nämnas FN:s konvention mot korruption, som antogs i december 2003. Konventionen täcker framför allt fyra områden: åtgärder som kan förebygga korruption; kriminalisering; internationellt samarbete; och beslag och återlämnande av tillgångar. Det är förhoppningen att konventionen särskilt skall bidra till att medel kan återvinnas som gömts undan på bankkonton oavsett var detta skett. Också den amerikanska samarbetsorganisationen (OAS) liksom Europarådet har antagit konventioner i ämnet. Det är löftesrikt att även den Afrikanska unionen antagit en konvention mot korruption. Den konventionen har dock svaga mekanismer för ansvarsutkrävande.
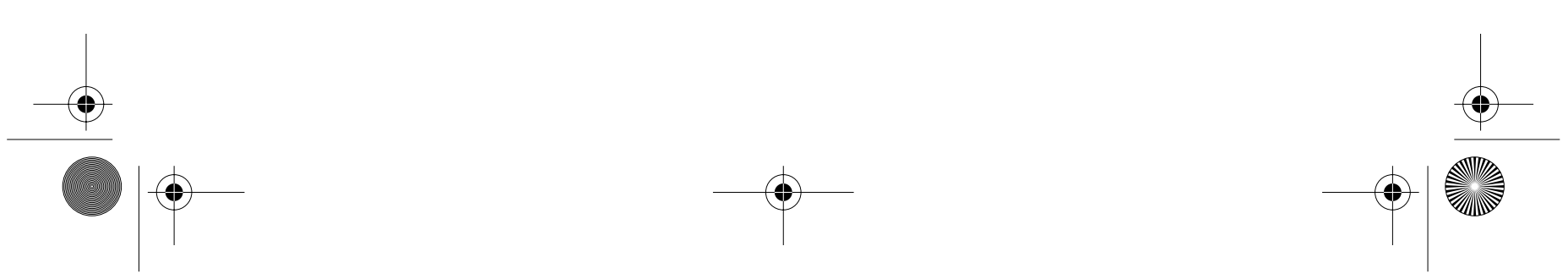
De konventioner som tillkommit är måhända inte särskilt effektiva som medel för brottsbekämpning men de har påverkat synen på bestickning som metod att hävda sig i internationella affärer såväl i den allmänna samhällsdebatten som inom företagen. Ändras synen på korruption som affärsmetod kan man häva det dilemma i vilket många företag befinner sig: hur kan man veta att inte konkurrenterna fortsätter att använda mutor? Det kan noteras att TI:s index BPI (se 1.3 ovan) visar att företag från de länder som är mest fria från korruption är minst benägna att betala mutor utomlands för att skaffa sig kontrakt.

Konventionerna kan även fă genomslag därför att det är kostsamt för företag att söka förmåner genom bestickning och därför att en sådan företagskultur också bäddar för illojalitet hos anställda. Inte minst viktigt är att konventionerna kan leda till att staters jurisdiktion sträcks ut, så att också bestickning utanför ett lands territorium kan leda till att ansvar krävs ut och egendom tas i beslag.

\subsection{Etik och kvasirättsliga regler}

Etiska riktlinjer och andra icke bindande normer om korruption får en allt mer framträdande plats. Denna form av «soft law» syftar till att skapa en standard för vad som är godtagbart. Ett skäl torde vara att det inte är ändamålsenligt att kriminalisera alla förfaranden som kan framstå som diskutabla och att det i många fall är svårt att precisera var gränsen skall gå mellan handlingar som kan godtas och sådana som är tvivelaktiga. Ett exempel är att Internationella Handelskammaren utfärdat riktlinjer, vilka för övrigt nyligen varit föremål för revision. I flera asiatiska länder, där korruptionsbekämpningen haft framgång, har man betonat etik och personligt ansvartagande. Bland annat i ett antal afrikanska länder har det vuxit fram s. k. ledarskapskoder. Sådana innehåller vanligen regler för ämbetsmän och politiska ledare. Dessa koder har utarbetats i vissheten om att ledarskiktet måste sätta tonen för ett samhällsstyre som är hederligt och öppet och åta sig att följa dessa regler. Icke bindande normer av här berört slag kan även komma till nytta på så sätt att de kan ge ledning för tillämpningen av straffrättsliga bestämmelser.
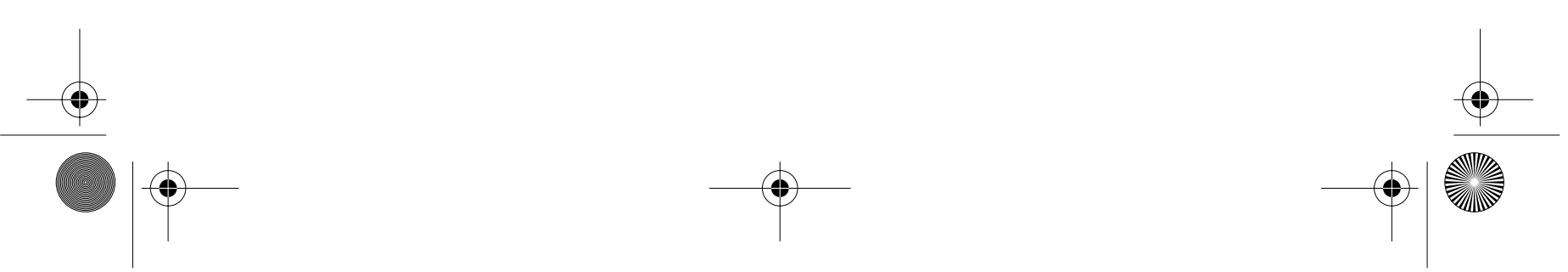


\subsection{Särskilda organ för korruptionsbekämpning?}

Erfarenheten tyder inte på att det finns fog för särskilda organ för särskilda typer av brottslighet, t.ex. skattebrott, narkotikasmuggling eller förskingringsbrott. Lika litet är det normalt mening att inrätta särskilda organ för korruptionsbekämpning vid sidan av de ordinarie organen. Det inbjuder till samordningsproblem, rivalitet och misstro. Men möjligen är situationen en annan i högkorrupta stater. I vart fall har man inrättat sådana organ i åtskilliga stater, t. ex. Bolivia. Indonesien är ett annat exempel där man har både ett särskilt organ för utredning av korruptionsbrott, i vilket polisen inte får medverka, och en specialdomstol för åtal för korruptionsbrott. Erfarenheterna i dessa bägge länder tycks vara ganska goda. Detsamma gäller än mer Independent Commission Against Corruption (ICAC) i Hongkong som anses ha haft stor betydelse för den framgångsrika korruptionsbekämpningen i detta landet.

Bilden är emellertid minst sagt nedslående i Kenya som framgår av följande citat:

«The Government has this morning formed an anticorruption squad to look into the conduct of the anticorruption commission, which has been overseeing the anticorruption task-force, which was earlier set to investigate the affairs of a Government ad hoc committee appointed earlier this year to look into the issue of high-level corruption among corrupt Government Officers." (statement released by the Attorney General of Kenya; The Daily Nation, October 28, 1997)

Frågan om specialorgan är central och omdiskuterad. Ett sådant organ kan framstå som den enda framkomliga vägen i vissa högkorrupta miljöer. Samtidigt finns en skepsis mot de framgångar som sådana organ i vissa fall gör anspråk på. Denna skepsis bottnar i insikten att de framsteg som gjorts kan vara hänförliga till reformer av det slag som berördes ovan (6.2). Det är vanligen svårt att påvisa ett klart samband mellan sådana reformer och en minskning av korruptionen. Över huvudtaget är det vanskligt att säkert belägga kausalsamband, därför att så många faktorer samverkar (ekonomiskt system, samhällsstyre, utvecklingsnivå, kultur osv.); sambanden går i «bägge riktningar».
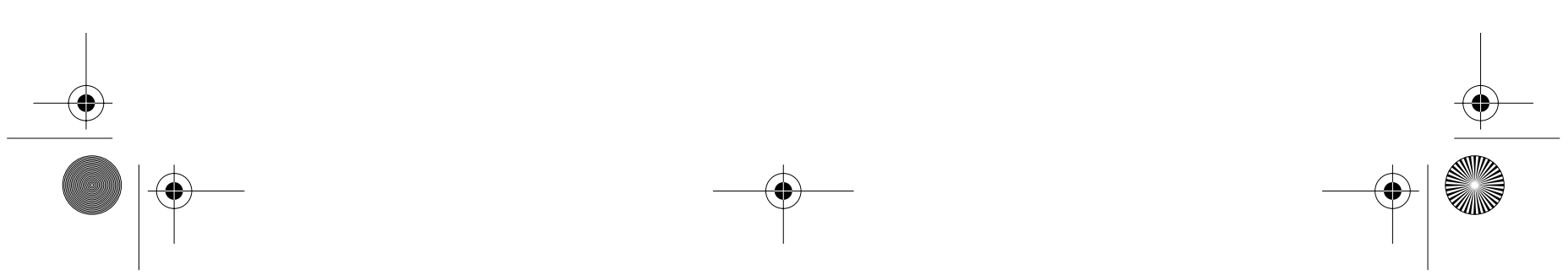


\subsection{Om lagstiftning och lagstiftningsteknik}

Ett helhetsgrepp på korruptionen måste motsvaras av ett juridiskt helhetsgrepp som ger stöd åt de olika insatsområdena. Många av de åtgärder som i realiteten motverkar korruption vidtas utan att det finns någon uttrycklig koppling till korruptionsbekämpningen. Som redan framgått finns det ingen allmängiltig definition av korruption. Det kan skifta från ett land till ett annat vad som faller in under begreppet. Typiskt sett är det av underordnat intresse exakt vilka företeelser som omfattas av begreppet. Det bör observeras att den definition som ges av begreppet korruption i den straffrättsliga lagstiftningen inte säger något om hur strängt lagstiftare ser på mutbrott. Handlingar som i ett land straffas som mutbrott kan i ett annat bestraffas som tjänstefel, bedrägeri, trolöshet mot huvudman osv. Man kan mycket väl tänka sig att en stat som är i avsaknad av straffbestämmelser som riktar sig mot mutbrott har en mycket sträng syn på sådana handlingar vilka emellertid betecknas som brott av något av de slag som just nämndes eller annat liknande brott. Bolivia är ett exempel på detta.

Lagstiftningstekniken bör ägnas eftertanke. Erfarenheten visar att allmänt hålla stadganden öppnar för godtycke och därmed för besticklighet. Möjligheterna till korruption är i stor uträckning ett utflöde av reglering och av brister hos en förvaltning som har uppgiften att tillämpa denna reglering. Det byråkratiska skönet kan begränsas genom att lagstiftningen görs precis och klara normer och standarder så långt möjligt sätts upp. Ett exempel är att normer fastställs för t. ex. infrastruktur så att en leverantör får svårare att köpa sig fri från brister i kvaliteten hos arbetet. Ett annat exempel är att skatter väljs som är lätta att administrera, t. ex. beskattning av fast egendom snarare än av inkomster. Gottfinnandet bör naturligtvis också hållas i strama tyglar genom att beslut kan överklagas.

\section{Avslutande reflektioner}

Den föregående exposén är en erinran om att korruptionen har vid spridning världen över - särskilt i syd och öst - och att korruptionen har stora skadeverkningar som särskilt drabbar fattiga människor. Den pekar också på att korruption är en undflyende företeelse på så vis att den är nära förbunden med brister i samhällsstyret, ytterst ett utföde av
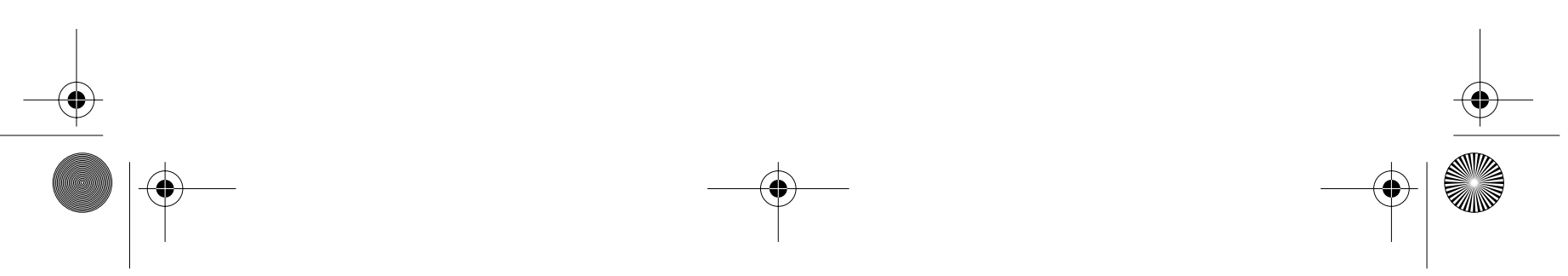
en svag stat. Grundorsaken till korruption är alltså både obestämd och sammansatt. Uppgiften att angripa korruption är därför minst sagt komplex.

Korruption är också svår att ringa in på så sätt att den samspelar med olika samhällsförhållanden på ett svårgripbart sätt. Relationen mellan korruption å ena sidan och fattigdom, utveckling, brottslighet, styresskick m. m. å den andra är svårbestämd. Vad är orsak och vad är verkan? Sambanden går i hög grad i bägge riktningarna.

Men exposén pekar även på att det är möjligt att angripa korruption med framgång. Det finns numera insikter om hur strategier för att angripa korruptionen bör utformas. Den svåra delen är att genomföra sådana strategier. Det krävs ett kraftfullt samarbete mellan alla nyckelgrupper i samhället - regering och parlament, det civila samhället, näringslivet osv. - för att man skall kunna få bukt med korruptionen.

Det föregående är även en indirekt förklaring varför många länder $i$ världen, de nordiska inbegripna, inte plågas av en djupt rotad korruption. De samhällsförhållanden som dessa strategier syftar till att skapa är redan för handen i dessa länder. Det gäller medborgerlig tillit till «systemet», ansvarsutkrävande öppenhet, ett gott ledarskap, begränsad överreglering, ett rättsväsende som åtnjuter förtroende, öppna ekonomier, hederliga val, statlig grundfinansiering av de politiska partierna o.s.v. Det krävs också att rättsväsendet förmår beivra den korruption som förekommer på ett effektivt sätt; de brottsbekämpande organen är inte avgörande utan rättsväsendet i sin helhet.

Antalet korruptionsfall som de rättsvårdande myndigheterna behandlar i t. ex. Norden är litet och man kan därför få intrycket att rättsväsendet, inklusive straffrätten, har bara marginell betydelse för korruptionsbekämpningen. Detta är dock en felsyn. Rättsväsendet är ytterst en garant för flertalet av de omständigheter som skapar ett korruptionsfritt samhälle. Det gäller t. ex. handlingars offentlighet, mötesoch yttrandefriheten, marknadstillträde, en korrekt behandlig av anbud i upphandlingar, korrekta allmänna val, pressens oberoende, ändamålsenlig lagstiftning, effektiva kanaler för medborgarnas klagomål o.s.v. Rättsväsendet har också den maktpåliggande uppgiften att kontrollera de organ som har att bekämpa korruptionen och att lagföra korrupta tjänstemän och politiker. Bara om denna lagföring är effektiv - och uppfattas som effektiv - bevaras medborgarnas förtroende för «syste-
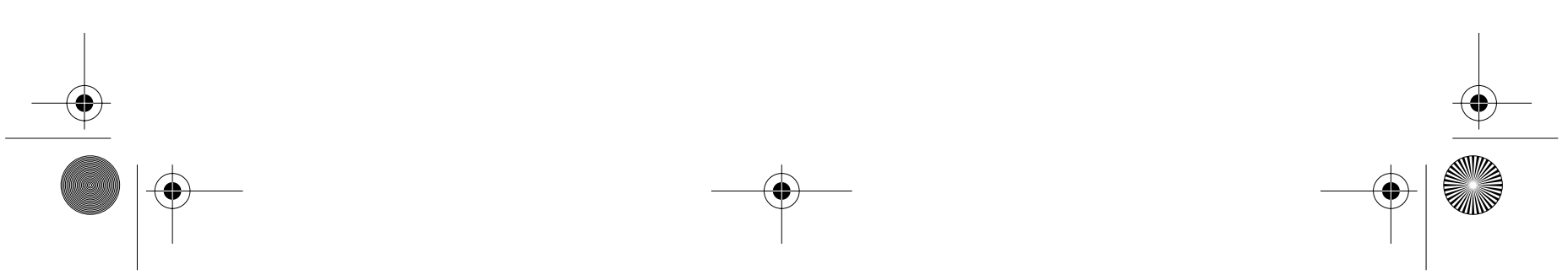
met». Det är i sin tur en förutsättning för medborgarnas lojalitet i den meningen att de tar avstånd från korruption och inte själva frestas att besticka eller ta mutor.

\section{Litteratur}

Litteraturen om korruption och korruptionsbekämpning är numera ytterst omfattande och svåröverskådlig. God information och värdefulla artiklar inhämtas enklast via Internet. Följande hemsidor kan rekommenderas:

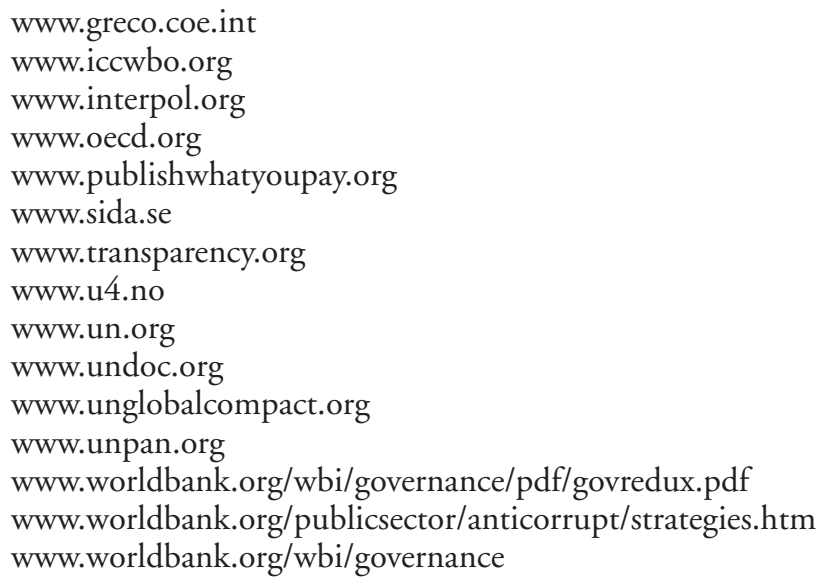

Ur litteraturen kan bl.a. följande nämnas:

Anger, J., Antikorruptionsstrategier i utvecklingssamarbetet, Sida 2004.

Prahab Bardan, «Corruption and Development: A Review of Issues», Journal of Economic Literature 35 (1997) s. 1320-1346

DAC Network on Governance, Synthesis of Lessons Learned of Donor Practices in Fighting Corruption, DCD/DAC/GOVNET (2003)1, OECD, Paris.

Rose-Ackerman, S., «Governance and Corruption», i: Bjørn Lomborg (red.), Global Crises, Global Solutions, Cambridge (UK), Cambridge University Press 2004, s. 301-354. 